\title{
Evaluation of a lower-powered analyzer and sampling system for eddy-covariance measurements of nitrous oxide fluxes
}

\author{
Shannon E. Brown ${ }^{1}$, Steve Sargent ${ }^{2}$, and Claudia Wagner-Riddle ${ }^{1}$ \\ ${ }^{1}$ School of Environmental Sciences, University of Guelph, Guelph, Ontario, Canada \\ ${ }^{2}$ Campbell Scientific Inc., Logan, Utah, USA \\ Correspondence: Shannon E. Brown (sbrown06@uoguelph.ca) \\ Received: 25 May 2017 - Discussion started: 4 August 2017 \\ Revised: 5 February 2018 - Accepted: 11 February 2018 - Published: 22 March 2018
}

\begin{abstract}
Nitrous oxide $\left(\mathrm{N}_{2} \mathrm{O}\right)$ fluxes measured using the eddy-covariance method capture the spatial and temporal heterogeneity of $\mathrm{N}_{2} \mathrm{O}$ emissions. Most closed-path tracegas analyzers for eddy-covariance measurements have largevolume, multi-pass absorption cells that necessitate high flow rates for ample frequency response, thus requiring highpower sample pumps. Other sampling system components, including rain caps, filters, dryers, and tubing, can also degrade system frequency response. This field trial tested the performance of a closed-path eddy-covariance system for $\mathrm{N}_{2} \mathrm{O}$ flux measurements with improvements to use less power while maintaining the frequency response. The new system consists of a thermoelectrically cooled tunable diode laser absorption spectrometer configured to measure both $\mathrm{N}_{2} \mathrm{O}$ and carbon dioxide $\left(\mathrm{CO}_{2}\right)$. The system features a relatively small, single-pass sample cell $(200 \mathrm{~mL})$ that provides good frequency response with a lower-powered pump $(\sim 250 \mathrm{~W})$. A new filterless intake removes particulates from the sample air stream with no additional mixing volume that could degrade frequency response. A single-tube dryer removes water vapour from the sample to avoid the need for density or spectroscopic corrections, while maintaining frequency response. This eddy-covariance system was collocated with a previous tunable diode laser absorption spectrometer model to compare $\mathrm{N}_{2} \mathrm{O}$ and $\mathrm{CO}_{2}$ flux measurements for two full growing seasons (May 2015 to October 2016) in a fertilized cornfield in Southern Ontario, Canada. Both spectrometers were placed outdoors at the base of the sampling tower, demonstrating ruggedness for a range of environmental conditions (minimum to maximum daily temperature range: -26.1 to $31.6^{\circ} \mathrm{C}$ ). The new system rarely required maintenance. An in situ frequency-
\end{abstract}

response test demonstrated that the cutoff frequency of the new system was better than the old system $(3.5 \mathrm{~Hz}$ compared to $2.30 \mathrm{~Hz}$ ) and similar to that of a closed-path $\mathrm{CO}_{2}$ eddy-covariance system $(4.05 \mathrm{~Hz})$, using shorter tubing and no dryer, that was also collocated at the site. Values of the $\mathrm{N}_{2} \mathrm{O}$ fluxes were similar between the two spectrometer systems (slope $=1.01, r^{2}=0.96$ ); $\mathrm{CO}_{2}$ fluxes as measured by the short-tubed eddy-covariance system and the two spectrometer systems correlated well (slope $=1.03, r^{2}=0.998$ ). The new lower-powered tunable diode laser absorption spectrometer configuration with the filterless intake and singletube dryer showed promise for deployment in remote areas.

\section{Introduction}

The concentration of $\mathrm{N}_{2} \mathrm{O}$ in the atmosphere is rising and is of concern as $\mathrm{N}_{2} \mathrm{O}$ has 298 times the global warming potential of $\mathrm{CO}_{2}$ (IPCC, 2013). Agricultural systems contribute a significant proportion of total global $\mathrm{N}_{2} \mathrm{O}$ emissions due to microbial soil processes (Davidson, 2009). The main drivers of microbial $\mathrm{N}_{2} \mathrm{O}$ emissions are soil conditions (e.g., soil oxygen, carbon, and nitrogen levels), but distal drivers such as nitrogen fertilization, dry-wet, and freeze-thaw cycles also exert control and result in $\mathrm{N}_{2} \mathrm{O}$ fluxes $\left(F_{\mathrm{N}_{2} \mathrm{O}}\right)$ that are highly variable in time ("hot moments") and in space ("hot spots"; Groffman et al., 2009; Molodovskaya et al., 2012). This sporadic nature of $F_{\mathrm{N}_{2} \mathrm{O}}$ necessitates continuous measurements covering areas large enough to capture the spatial heterogeneity of the fluxes to sufficiently quantify total emissions from agricultural systems (Flechard et al., 2007; Jones et al., 2011; Shurpali et al., 2016). The eddy-covariance (EC) 
technique gives long-term, continuous, and spatially integrated measurements, which can fully capture $F_{\mathrm{N}_{2} \mathrm{O}}$. Advances in technology for $\mathrm{N}_{2} \mathrm{O}$ analyzers have increased the number of long-term $\mathrm{N}_{2} \mathrm{O}$ measurement campaigns using EC methods (Mishurov and Kiely, 2010; Molodovskaya et al., 2012; Merbold et al., 2014; Huang et al., 2014; Rannik et al., 2015; Shurpali et al., 2016; Wang et al., 2016). However, the application has been limited to sites with high-quality power or short-term deployment. Locations with agricultural $\mathrm{N}_{2} \mathrm{O}$ emissions are often rural areas where it may be impractical and expensive to install permanent power infrastructure for long-term $F_{\mathrm{N}_{2} \mathrm{O}}$ EC flux measurements.

Gas analyzers used in EC systems require fast responses to distinguish the high frequencies of concentration fluctuations (McBean, 1972; Leuning and Judd, 1996). High-frequency concentration fluctuations can be attenuated by line averaging within the sample cell, as well as sample mixing within various system components, such as intake tubing, dryers, filters, and rain caps (Moore, 1986; Massman, 2000). Analyzer frequency response often represents a significant proportion of the total high-frequency losses (Horst, 1997; Kroon et al., 2010b), but these sampling system components may also significantly degrade system frequency response (Aubinet et al., 2016). Modern closed-path analyzers for $\mathrm{CO}_{2} \mathrm{EC}$ fluxes achieve high-frequency response with low-power pumps by using small sample cells (6 or $16 \mathrm{~mL}$ ) that operate near ambient pressure (Burba et al., 2010; Novick et al., 2013). The volume of sampling system components is minimized to preserve the frequency response without excessive flow restriction that would increase power requirements for the pump or exceed the range of the sample-cell pressure sensor (Aubinet et al., 2016; Ma et al., 2017).

In contrast, all $\mathrm{N}_{2} \mathrm{O}$ analyzers tested in a recent $\mathrm{EC}$ field intercomparison have large sample cells $(\sim 500 \mathrm{~mL})$ that must operate at significantly reduced pressure (50 to $120 \mathrm{mb}$ ), necessitating high flow rates (12 to $17 \mathrm{~L} \mathrm{~min}^{-1}$; Rannik et al., 2015). The high flow rate and low pressure require the use of a relatively high-power pump (500 to $1000 \mathrm{~W}$ ). Reducing the volume of the sample cell and sampling system components is a means of maintaining good frequency response at a lower flow rate while reducing the power requirements of $\mathrm{N}_{2} \mathrm{O}$ EC systems. Using a dryer on the intake line may degrade system frequency response but can eliminate uncertainties associated with spectroscopic corrections for line broadening due to water vapour (Neftel et al., 2010) and density corrections (Webb et al., 1980). The typically high sample flow rates require the use of multi-tube dryers to achieve an acceptable residual humidity. However, laminar flow within the dryer degrades system frequency response because air velocity varies from the centre to the wall of the tube (Leuning and Judd, 1996), and multi-tube dryers can further degrade frequency response if the flow varies among the individual tubes. This problem cannot be overcome by simply increasing flow because a higher flow would require a larger dryer. Alternatively, analyzers with smaller sample cells re- quire lower sample flow, allowing the use of single-tube dryers and lower-powered pumps to achieve the frequency response required for EC measurements.

An upgraded version of a first-generation tunable diode laser absorption spectrometer (TDLAS; Edwards et al., 2003) has recently been made commercially available (TGA200A, Campbell Scientific Inc., Logan, Utah, USA). The previous model was suitable for long-term $\mathrm{N}_{2} \mathrm{O}$ flux measurements for a variety of agricultural and forested sites (Scanlon and Kiely, 2003; Pihlatie et al., 2005; Pattey et al., 2006; Mishurov and Kiely, 2010; Molodovskaya et al., 2012). The upgraded model has been designed to reduce power consumption of EC measurement systems by reducing the volume of the sample cell. This was done without changing the path length, thereby preserving measurement precision. The smaller sample cell allows a lower flow rate, enabling the use of a single-tube dryer that maintains frequency response better than high-capacity, multi-tube dryers. Adapting a new vortex intake - originally developed for use with a $\mathrm{CO}_{2} / \mathrm{H}_{2} \mathrm{O}$ EC analyzer (Ma et al., 2017) - to the $\mathrm{N}_{2} \mathrm{O}$ analyzer should further improve the frequency response as this device removes particulates from the air stream without adding a significant mixing volume. The vortex intake has the additional advantage of not requiring a traditional filter that can clog over time, restricting flow to the analyzer, and requiring maintenance. This is an important aspect of EC system design for long-term studies because, as stated by Nelson et al. (2004), all components need to be sufficiently rugged to withstand exposure to environmental conditions and run reliably for long time periods with minimal maintenance.

Cutoff frequencies are often used to characterize the frequency response of EC analyzers and systems (McBean, 1972; Nelson et al., 2004; Detto et al., 2011; Rannik et al., 2015) and for correcting flux values for high-frequency losses (Moore, 1986; Horst, 1997; Aubinet et al., 2000; Massman, 2000; Massman and Lee, 2002). Determining frequency response using field-measured cospectra (Aubinet et al., 2000; Ibrom et al., 2007) is challenging for $\mathrm{N}_{2} \mathrm{O}$ EC systems as this requires a strong concentration signal occurring simultaneously with environmental conditions appropriate for scaling with temperature spectra. Direct characterizations are more appropriate for $\mathrm{N}_{2} \mathrm{O}$ analyzers since emission events may occur for only a few days in a year, reducing the likelihood of ideal conditions for cospectral analyses. Similarly, evaluating system lag times of closed-path $\mathrm{N}_{2} \mathrm{O}$ analyzers used for EC flux processing with the standard crosscorrelation method requires a strong signal (Kroon et al., 2010b; Neftel et al., 2010). Directly measuring lag times will give a better estimate of the tube delay for periods with low $\mathrm{N}_{2} \mathrm{O}$ signals.

We present the first field trial of a new TDLAS with an optimized sampling system, operating at lower flow rates with a lower-powered pump. Continuous $F_{\mathrm{N}_{2} \mathrm{O}}$ measurements are presented over two growing seasons for an agricultural site in a cold climate. The system was evaluated for overall perfor- 
mance of the instrument in terms of ease of operation, data quality, and suitability for EC measurements. $\mathrm{N}_{2} \mathrm{O}$ fluxes measured by the new TDLAS were compared to those measured by the previous-generation TDLAS and $\mathrm{CO}_{2}$ fluxes $\left(F_{\mathrm{CO}_{2}}\right)$ were compared to fluxes measured by a short-tubed $\mathrm{CO}_{2}$ analyzer. A novel method for determining EC system frequency response and lag time was conducted in situ to determine the analyzer frequency response under field operating conditions.

\section{Methods}

\subsection{Study site}

Flux measurements took place at the Elora Research Station, Elora, Ontario, Canada (43.327. $\left.8^{\prime} \mathrm{N}, 80.24^{\circ} 20.4^{\prime} \mathrm{W}\right)$, from May 2015 to October 2016 as a part of a four-plot fluxgradient study on the effect of nitrogen fertilizer management practices on $F_{\mathrm{N}_{2} \mathrm{O}}$. The four 4 ha plots were located within a larger 30 ha aerodynamically homogeneous and flat field (Fig. 1a) under the same crop management practices. The soil at the site was a Guelph silt loam (fine loamy, mixed, mesic Glossoboric Hapludalf). Corn was planted on 10 May 2015 and again on 5 May 2016. Urea fertilizer was broadcastapplied at the time of planting in both years at a rate of $150 \mathrm{~kg} \mathrm{ha}^{-1}$ to the plot where instrumentation was set up (Fig. 1a). Corn grew to a maximum height of approximately $2.5 \mathrm{~m}$ each summer. Harvest for 2015 started on 27 October and completion was delayed due to rain until 2 November. The field was tilled immediately afterwards, leaving a baresoil surface from 2 November 2015 to 30 May 2016 when the corn emerged. Harvest in 2016 occurred on 7 October. The field plot was located $400 \mathrm{~m}$ from an Environment Canada weather station that measured supporting variables of mean wind direction, air temperature, pressure, and precipitation.

\subsection{Eddy-covariance measurements}

An EC system (CPEC200, Campbell Scientific Inc., Logan, Utah, USA) was installed in the southeast corner of the 4 ha plot (Fig. 1a, c) and was comprised of a sonic anemometer (CSAT3A) to measure three-dimensional wind and sonic temperature, a closed-path infrared gas analyzer (EC155) to measure mixing ratios of $\mathrm{CO}_{2}$ and $\mathrm{H}_{2} \mathrm{O}$, and a data logger (CR3000). The sonic anemometer was oriented towards the predominant wind direction $\left(270^{\circ}\right.$; Fig. 1b). Two TDLAS were added to this system (TGA100A and TGA200A, Campbell Scientific Inc., Logan, Utah, USA; see details below). Each measured mixing ratios of $\mathrm{N}_{2} \mathrm{O}$ and $\mathrm{CO}_{2}$. The analyzers include temperature-controlled, weatherproof cases that allowed them to be placed on two cinder blocks set on the ground at the base of the tower (Fig. 1c). Details on the operation of each gas analyzer are given below. The EC measurements were made at a height of $2.0 \mathrm{~m}$ when the surface was bare; the intakes and sonic anemometer were raised to
$1.75 \mathrm{~m}$ above the canopy top throughout the growing seasons. Data from the sonic anemometer and all three analyzers were recorded at a sampling rate of $10 \mathrm{~Hz}$. Each gas analyzer included a user-configurable digital filter set for a $5 \mathrm{~Hz}$ cutoff frequency to avoid aliasing.

\subsection{Gas analyzers}

The operating principles of the TDLAS used can be found in Edwards et al. (2003) and Wagner-Riddle et al. (2005). Briefly, a temperature-controlled laser emits a beam at an absorption wavelength of the gas species of interest. This beam is split and directed through the sample cell as well as a reference cell supplied with a known reference gas. The laser wavelength is swept across an individual absorption line by adjusting the laser current. This produces the absorption spectrum, measured by detectors at the ends of the reference and sample cells. The mixing ratio in the sample cell is calculated from the ratio of the spectral absorbance of the reference and sample cells. Both TDLASs are capable of simultaneous measurement of multiple trace gases on separate absorption lines (dual-ramp mode). For periods during this study, the analyzers were set to measure the absorption of $\mathrm{N}_{2} \mathrm{O}$ and ${ }^{13} \mathrm{CO}_{2}$.

Table 1 lists the equipment and measurement mode used for each analyzer through the measurement campaign. Operating configurations of $\mathrm{N}_{2} \mathrm{O}$ analyzers used in Rannik et al. (2015) are given for comparison. The analyzers included enclosure temperature controllers to maintain temperatures of $20^{\circ} \mathrm{C}$ in winter and $40^{\circ} \mathrm{C}$ in summer. Flow from the reference gas cylinders was set at $10 \mathrm{~mL} \mathrm{~min}^{-1}$. Analyzer calibrations were performed shortly after the initial installation and repeated each time a reference cylinder was replaced. Additional information on calibration and correction of ${ }^{13} \mathrm{CO}_{2}$ to total $\mathrm{CO}_{2}$ can be found in the Supplement.

The "legacy" TDLAS (TGA100A, manufactured in 2005, hereafter referred to as TDLAS-LN) used a cryogenically cooled, lead salt diode laser operating at $83.5 \mathrm{~K}$ and $2243.11 \mathrm{~cm}^{-1}\left(\mathrm{~N}_{2} \mathrm{O}\right)$ and $2243.585 \mathrm{~cm}^{-1}\left(\mathrm{CO}_{2}\right)$. The TDLAS-LN required twice-weekly filling of the laser dewar with liquid nitrogen. This analyzer was operated in a dual-ramp mode measuring both $\mathrm{N}_{2} \mathrm{O}$ and $\mathrm{CO}_{2}$ throughout the measurement campaign, following a typical airsampling configuration for EC measurements (Fig. 1d; see also Mammarella et al., 2010; Mishurov and Kiely, 2010; Molodovskaya, 2012; Rannik et al., 2015). Air was sampled through a $6 \mathrm{~mL}$ rain-shielded intake (part number 17882 , Campbell Scientific, Inc., Logan, Utah, USA) and a dryer assembly (PD1000, Campbell Scientific, Inc., Logan, Utah, USA), which included a $2 \mu$ m polypropylene filter element in a low-volume, high-flow filter holder, and a multi-tube dryer (200-tube, 1.2 m Nafion $^{\text {TM }}$ dryer element; Perma Pure, Lakewood, New Jersey, USA). A tee fitting and needle valves split the flow between dryer purge $\left(3 \mathrm{~L} \mathrm{~min}^{-1}\right)$ and sample flow directed to the analyzer $\left(14.5 \mathrm{~L} \mathrm{~min}^{-1}\right.$; Fig. 1d). Tub- 

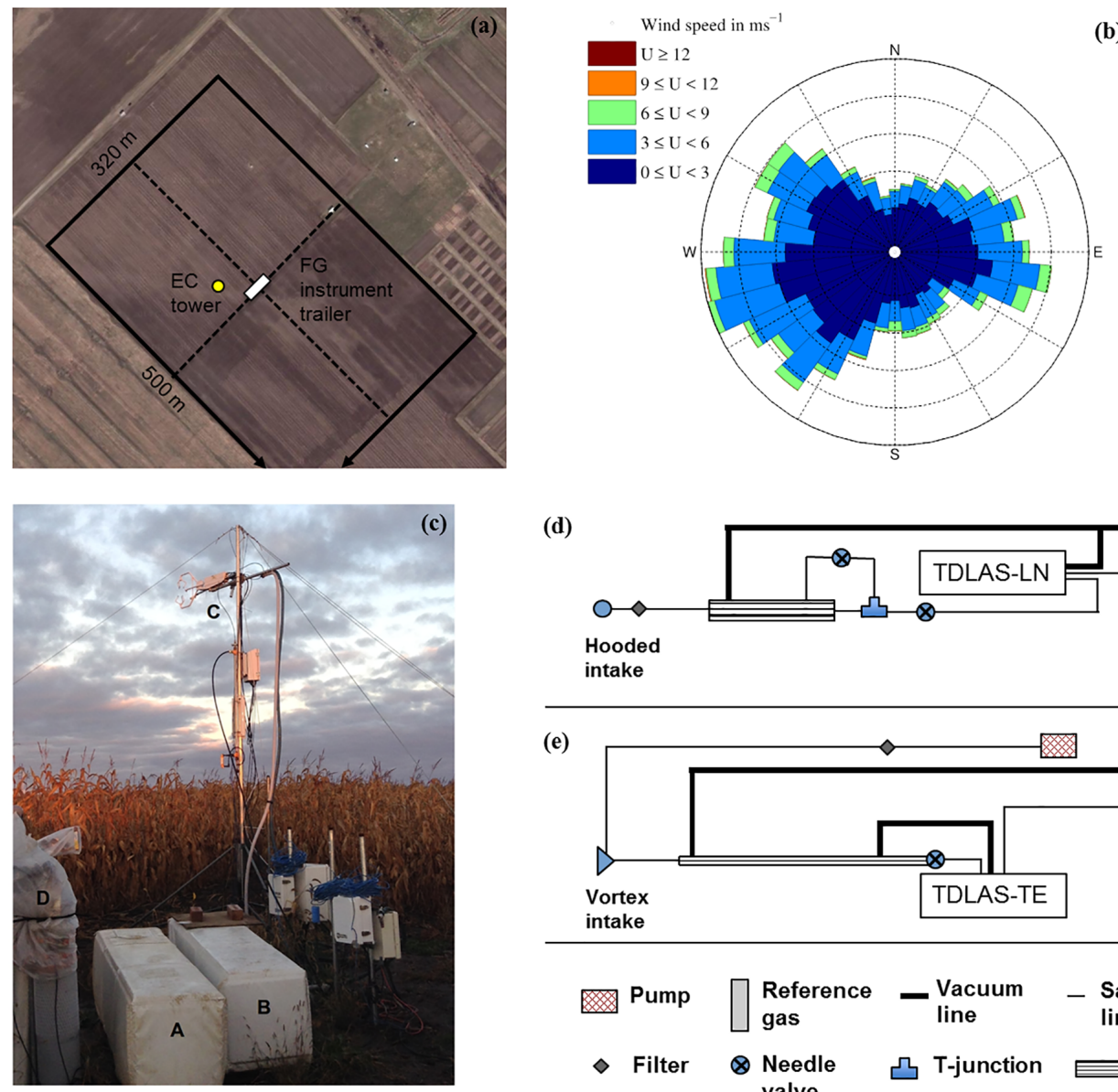

(d)

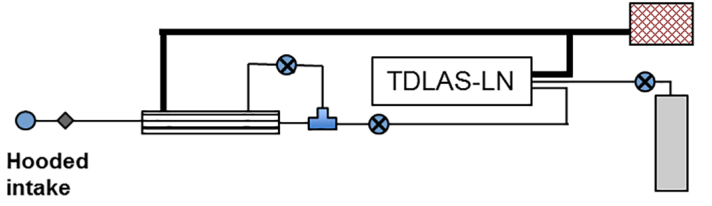

(e)
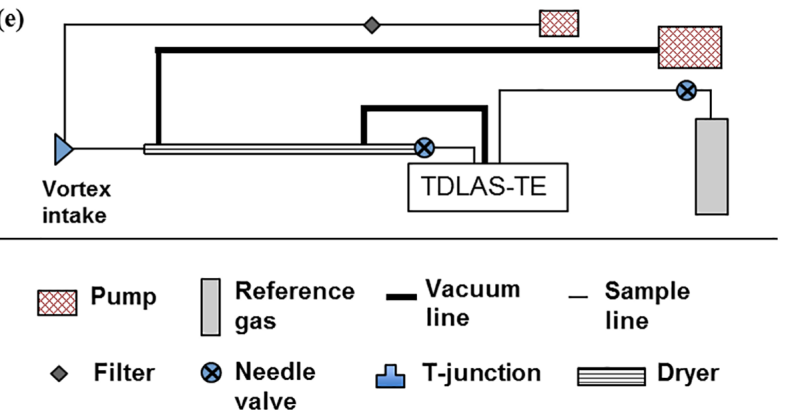

Figure 1. Descriptions of the field site and eddy-covariance instrumentation. (a) Layout of the field site. Dashed lines indicate the borders of the field treatments used in the larger four-plot flux gradient (FG) study. Instrumentation for that study was housed in the indicated instrumentation trailer located in the centre of the field. Solid lines outline the entire field. (b) Wind rose of the wind speeds and direction observed during the field study. (c) Configuration of the analyzers at the EC tower; A is TDLAS-LN, B is TDLAS-TE, C is EC155, and D is reference gases for the $\mathrm{N}_{2} \mathrm{O}$ analyzers. (d) Schematic of TDLAS-LN sampling system with inline filter and multi-tube dryer. (e) Schematic of TDLAS-TE sampling system with vortex intake and single-tube dryer.

ing between the intake, dryer assembly, and the analyzer was $4.3 \mathrm{~mm}$ ID Synflex ${ }^{\mathrm{TM}}$ tubing. The total length of tubing (plus dryer) from the intake to the analyzer was $6 \mathrm{~m}$ from 10 May to 8 July 2015 , at which time the tubing length was increased to $10 \mathrm{~m}$ to accommodate the increase in canopy height. A $950 \mathrm{~W}$ rotary vane pump (RB0021, Busch Vacuum Technics, Inc., Boisbriand, Québec, Canada) was connected to the analyzer using $\sim 50 \mathrm{~m}$ of $25.4 \mathrm{~mm}$ ID PVC suction hose (Tigerflex K100, Kuri Tec, Brantford, Ontario, Canada), to draw air through the analyzer and the dryer purge (Fig. 1d). The volume of the sample cell of TDLAS-LN was $480 \mathrm{~mL}$. This setup is similar to the TGA100A used by Rannik et al. (2015), although for the present study the original filter holder (Gelman 1235, Pall Corp.), included as part of the dryer assembly, was updated to a newer design (part number 20553, Campbell Scientific, Inc., Logan, Utah, USA) with lower volume ( $5 \mathrm{~mL}$ compared to $20 \mathrm{~mL}$ ). Filter elements were replaced approximately every 2 weeks. The nominal sample-cell pressure was $58 \mathrm{mb}$ throughout the measurement campaign.

The new $\mathrm{N}_{2} \mathrm{O}$ analyzer (TGA200A, hereafter referred to as TDLAS-TE) was similar to the TDLAS-LN with two major upgrades: a smaller-diameter sample cell and a roomtemperature laser. It used a distributed feedback interband cascade laser (DFB ICL, nanoplus Nanosystems and Technologies $\mathrm{GmbH}$, Gerbrunn, Germany) that was cooled thermoelectrically as opposed to with liquid nitrogen. The laser temperature was set to $-1{ }^{\circ} \mathrm{C}$ and the laser current was tuned to measure $\mathrm{N}_{2} \mathrm{O}$ at $2237.7 \mathrm{~cm}^{-1}$ and $\mathrm{CO}_{2}$ at $2237.3 \mathrm{~cm}^{-1}$ from 10 to 29 May 2015, when the laser was configured to measure $\mathrm{N}_{2} \mathrm{O}$ at $2235.5 \mathrm{~cm}^{-1}$ to assess performance of the laser in single-ramp mode for approximately 2 months. On 31 July 2015, the laser was switched back to dual-ramp mode until 31 March 2016. On this date, a new $\mathrm{N}_{2} \mathrm{O}$-only laser was 
Table 1. Sampling system details for each analyzer throughout the measurement campaign. Changes to equipment during the experimental period are indicated. Operating configurations of $\mathrm{N}_{2} \mathrm{O}$ analyzers used in Rannik et al. (2015) are given for comparison.

\begin{tabular}{|c|c|c|c|c|c|c|c|c|}
\hline & Filter & Dryer & Pump & $\begin{array}{r}\text { Flow } \\
\left(\mathrm{L} \mathrm{min}^{-1}\right)\end{array}$ & $\begin{array}{r}\text { Cell } \\
\text { pressure } \\
(\mathrm{mb})\end{array}$ & $\begin{array}{r}\text { Cell } \\
\text { volume } \\
(\mathrm{mL})\end{array}$ & $\begin{array}{r}\text { Tube } \\
\text { ID } \\
(\mathrm{mm})\end{array}$ & $\begin{array}{r}\text { Tube } \\
\text { length } \\
(\mathrm{m})\end{array}$ \\
\hline \multicolumn{9}{|l|}{ Current study } \\
\hline \multicolumn{9}{|l|}{ TDLAS-LN } \\
\hline Before 8 Jul 2015 & $2 \mu \mathrm{mpp}$ & multi-tube & rotary vane & 14.5 & 58 & 480 & 4.3 & 6 \\
\hline After 8 Jul 2015 & $2 \mu \mathrm{m} p$ & multi-tube & rotary vane & 14.5 & 58 & & 4.3 & 10 \\
\hline \multicolumn{9}{|l|}{ TDLAS-TE } \\
\hline Before Jun 2015 & $2 \mu \mathrm{m}^{\mathrm{pp}}$ & multi-tube & rotary vane & 14.5 & 59 & 200 & 4.3 & 6 \\
\hline After 24 Jun 2015 & vortex & single tube & scroll & 3.5 & 32 & & 2.2 & 9.1 \\
\hline \multicolumn{9}{|l|}{ EC155 } \\
\hline Before Feb 2016 & $20 \mu \mathrm{m}^{\mathrm{ss}}$ & none & diaphragm & 7 & 950 & 6 & 2.7 & 0.6 \\
\hline After 4 Feb 2016 & vortex & & & 6 & 910 & & 2.2 & 0.6 \\
\hline \multicolumn{9}{|c|}{ From Rannik et al. (2015) } \\
\hline \multirow{4}{*}{\multicolumn{4}{|c|}{$\begin{array}{l}\text { TGA100A (Campbell Scientific Inc.) } \\
\text { CW-TILDAS-CS (Aerodyne Research Inc.) } \\
\text { N2O/CO-23d (Los Gatos Research Inc.) } \\
\text { QC-TILDAS76-CS (Aerodyne Research Inc.) }\end{array}$}} & 17 & 50 & 480 & 4 & 17.8 \\
\hline & & & & 13.2 & 53 & 500 & 4 & 16 \\
\hline & & & & 11.6 & 117 & $408^{*}$ & 8 & 16 \\
\hline & & & & 13.5 & 53 & 500 & 4 & 8.5 \\
\hline
\end{tabular}

* From LGR user manual. Notes: pp is polypropylene; ss is stainless steel.

installed in the TDLAS-TE. This laser operated at $-2.4{ }^{\circ} \mathrm{C}$ at $2208.6 \mathrm{~cm}^{-1}$.

The sample cell of TDLAS-TE has a similar length $(1.5 \mathrm{~m})$ compared to the TDLAS-LN, but a smaller inner diameter (12.7 $\mathrm{mm}$ compared to $18.8 \mathrm{~mm}$ ). The smaller inner diameter gives the newer sample cell a volume of $200 \mathrm{~mL}$, a reduction of $280 \mathrm{~mL}$ from the original size. From 10 May to 22 June 2015 the TDLAS-TE sampling system (intake assembly, dryer, and pump) was similar to that of the TDLAS-LN. The TDLAS-TE sampling system was replaced on 24 June 2015 with a new prototype design including a vortex intake and single-tube dryer (Fig. 1e), optimized to take advantage of the smaller sample-cell volume. The intake assembly and filter were replaced with a vortex intake that removes particulates without a traditional filter (US patent no. 9217 692). The vortex intake was adapted for this application by extending the length of the sample tube ( $2.2 \mathrm{~mm}$ ID stainless steel) to $1.1 \mathrm{~m}$ and by providing a separate high-capacity filter (Numatics PXB-02, ASCO Numatics, Florham Park, New Jersey, USA) and diaphragm pump (E163-11-120, ParkerHannifin, Inc. Hollis, NH) for the bypass flow. On 24 December 2015 this pump was replaced by one designed for long-term continuous use (L061B-11, Parker-Hannifin, Inc. Hollis, New Hampshire, USA). The multi-tube dryer was replaced with a prototype design using a single Nafion ${ }^{\circledR}$ tube (2.2 mm ID, $7.3 \mathrm{~m}$ long TT-110, Perma Pure LLC, Lakewood, New Jersey, USA). The tube was housed in a large- diameter $(25.4 \mathrm{~mm})$ flexible shell to allow it to be purged in reflux mode with little pressure drop. A needle valve at the outlet of the dryer controlled the sample-flow rate to $3.5 \mathrm{~L} \mathrm{~min}^{-1}$. The total length of the intake assembly and dryer was $9.1 \mathrm{~m}$. A short $(0.1 \mathrm{~m})$ tube $\left(4.3 \mathrm{~mm}\right.$ ID Synflex $\left.{ }^{\mathrm{TM}}\right)$ connected the needle valve to the analyzer inlet. A lowerpowered $(250 \mathrm{~W})$ dry scroll pump (nXDS6i, Edwards Ltd., West Sussex, UK) pulled the sample air through the intake assembly, dryer, and analyzer via approximately $50 \mathrm{~m}$ of $25.4 \mathrm{~mm}$ ID PVC suction hose (Tigerflex K100, Kuri Tec, Brantford, Ontario, Canada; Fig. 1e). The nominal samplecell pressure was $59 \mathrm{mb}$ at the start of the measurement campaign and set to $35 \mathrm{mb}$ after the new sampling system was installed on 24 June 2015.

$\mathrm{CO}_{2}$ and $\mathrm{H}_{2} \mathrm{O}$ fluxes were measured with a closed-path EC system (CPEC200) that included the gas analyzer (EC155) and sonic anemometer (CSAT3A), as well as the sample pump, enclosures, and mounting hardware. Details on the EC155 analyzer can be found in Novick et al. (2013). This CPEC200 system was configured with the manufacturer's valve module for automatic zero and span, as well as a scrub module to supply dry, $\mathrm{CO}_{2}$-free air for setting zero on the analyzer (see details in the Supplement). The system was configured to automatically set the analyzer to zero and $\mathrm{CO}_{2}$ span daily at 01:00. The EC155 was reconfigured on 10 February 2016 with the production version of the vortex intake/sample-cell prototype that was tested by Ma et 
al. (2017). Nominal flow settings of $8 \mathrm{~L} \mathrm{~min}^{-1}$ total flow, with $6 \mathrm{~L} \mathrm{~min}^{-1}$ through the EC155 sample cell and $2 \mathrm{~L} \mathrm{~min}^{-1}$ for the vortex bypass, were used.

\subsection{Frequency-response test}

The impulse response method (Sargent, 2012) was used in situ to measure the frequency response of each EC system and derive the tube delay $\left(t_{\text {del }}\right)$, cutoff frequency $\left(f_{\mathrm{c}}\right)$, and effective time constant $\left(\tau_{\mathrm{e}}\right)$. Briefly, this method entails injecting an impulse of high $\mathrm{N}_{2} \mathrm{O}$ and $\mathrm{CO}_{2}$ concentration into the sample air stream. Measuring the response to this impulse and taking the Fourier transform of this result gives the frequency response. This gives a conservative estimate of the frequency response of the system, as any attenuation of high frequencies caused by the test method is included in the system frequency response.

The impulse responses were measured in situ for each analyzer by injecting high-concentration $\left(2500 \mathrm{ppm} \mathrm{N}_{2} \mathrm{O}\right.$ and $30000 \mathrm{ppm} \mathrm{CO}_{2}$ ) gas directly into the intake with a fastacting solenoid valve (VHS micro dispense valve, The Lee Co., Westbrook, Connecticut, USA) driven with a spike-andhold driver (part number IECX0501350AA, The Lee Co.) every $10 \mathrm{~s}$, as controlled by a data logger. For the TDLAS-TE and EC155, which were equipped with the vortex intake, the dispense valve nozzle was inserted into the rain cap end for a test of the complete system. The TDLAS-LN used a rain cap that did not permit this direct injection. This rain cap was removed and replaced with a small adapter to mount the valve. The dispense valve was driven open for less than $5 \mathrm{~ms}$ for each pulse. For the $\mathrm{N}_{2} \mathrm{O}$ analyzers, frequency response was measured at various pressures, including the standard operating pressure (TDLAS-LN: 29, 38, 45, and $58 \mathrm{mb}$; TDLASTE: $28,30,35$, and $43 \mathrm{mb}$ ). These pressures were achieved by adjusting the needle valve that sets the sample flow. The EC155 frequency response was measured with the production version of the vortex intake assembly. The concentration data and the voltages to the solenoid valve were recorded at $20 \mathrm{~Hz}$ for $20 \mathrm{~min}$ per test.

The impulse response was calculated by subtracting the average ambient background $\mathrm{N}_{2} \mathrm{O}$ or $\mathrm{CO}_{2}$ concentrations from the data, overlaying the multiple $10 \mathrm{~s}$ periods, and then taking an average of the responses. The $t_{\text {del }}$ was calculated as the delay from the valve open signal to the peak of the impulse response, minus processing time for the analyzer (750, 372 , and $800 \mathrm{~ms}$, respectively, for TDLAS-LN, TDLAS-TE, and EC155). This tube delay represents the physical travel time through the sampling system and into the analyzer sample cell.

The frequency response was calculated as the normalized amplitude of the Fourier transform of the impulse response. The $f_{\mathrm{c}}$ was determined graphically as the frequency at which the frequency response reached a value of $1 / \sqrt{ } 2$. Following common practice, we compared this frequency response to a linear, first-order system (Moore, 1986; Horst, 1997; Mass- man, 2000; Massman and Lee, 2002; Ibrom et al., 2007). This transfer function is often related to electronic circuits, but it also describes transfer function of an ideal mixing volume (Horst, 1997). The amplitude of the transfer function $\left(T_{\mathrm{FR}}\right)$ is

$T_{\mathrm{FR}}=\frac{1}{\sqrt{1+\left(\frac{f}{f_{\mathrm{c}}}\right)^{2}}}$.

Alternately, the transfer function may be parametrized by an effective time constant $\left(\tau_{\mathrm{e}}\right)$, calculated using

$\tau_{\mathrm{e}}=\frac{1}{2 \pi f_{\mathrm{c}}}$.

Theoretical residence times $\left(\tau_{\text {res }}\right)$ of the analyzer sample cells were calculated based on the sample-cell volume, pressure, and flow rates from Table 1 . Theoretical cutoff frequencies $\left(f_{\mathrm{c}, \mathrm{t}}\right)$ and corresponding theoretical effective time constants $\left(\tau_{\mathrm{e}, \mathrm{t}}\right)$ were calculated from $\tau_{\text {res }}$ using different models for multi-pass and single-pass sample cells. Multi-pass sample cells, which tend to be relatively short for a given volume with low length-to-diameter ratios, are often modelled with the assumption of perfect mixing $\left(\tau_{\mathrm{e}, \mathrm{t}}=\tau_{\text {res }}\right.$; Nelson et al., 2004). In contrast, EC155, TDLAS-LN, and TDLASTE have higher length-to-diameter ratios and have relatively long, narrow sample cells. For these analyzers the theoretical frequency response is modelled assuming no mixing in the sample cell, which is analogous to line averaging in a sonic anemometer when the sonic path is aligned with the wind vector. The amplitude transfer function for line averaging is (Mitsuta, 1966)

$T_{\mathrm{LA}}=\sqrt{\sin ^{2}\left(\pi \tau_{\text {res }} f\right) /\left(\pi \tau_{\text {res }} f\right)^{2}}$.

This transfer function has an approximate cutoff frequency of

$f_{\mathrm{c}, \mathrm{t}}=\frac{2.78}{2 \pi \tau_{\mathrm{res}}}$.

The corresponding effective time constant from Eq. (2) is

$\tau_{\mathrm{e}, \mathrm{t}}=\frac{1}{2 \pi f_{\mathrm{c}, \mathrm{t}}}=\frac{\tau_{\mathrm{res}}}{2.78}$.

\subsection{Flux calculations}

Fluxes were calculated as the covariance between fluctuations of the scalar concentration $(s)$ and the vertical wind velocity $(w)$ :

$F_{s}=\overline{w^{\prime} s^{\prime}}$,

where $s$ is the mixing ratio of either $\mathrm{N}_{2} \mathrm{O}$ or $\mathrm{CO}_{2}$. 
Fluxes were calculated for $30 \mathrm{~min}$ time intervals in Matlab $^{\mathrm{TM}}$ using modifications to functions from Sturm et al. (2012). The vertical wind was despiked and then rotated using a double rotation (Aubinet et al., 2012; Kaimal and Finnigan, 1994). The high-frequency concentration data for all analyzers were despiked and filtered according to instrument diagnostic codes. Concentration measurements from both $\mathrm{N}_{2} \mathrm{O}$ analyzers were filtered for periods of equipment maintenance or malfunction. All concentrations measured by TDLAS-TE and the EC155 were linearly detrended. Concentration data from TDLAS-LN were linearly detrended until winter of 2016 when the concentration signal periodically indicated optical fringing of the laser. A Chebyshev filter was used to detrend and remove the artificial low-frequency fluctuations for those $30 \mathrm{~min}$ periods. The $30 \mathrm{~min}$ flux values were filtered for low wind speed conditions (friction velocity $\left(u_{*}\right)<0.1 \mathrm{~m} \mathrm{~s}^{-1}$ ) and wind direction of 60 to $120^{\circ}$ (shadow of instrument tower). Vibrations from strong winds against the side of TDLAS-LN caused increased concentration noise. This occurred during periods when the field was bare and mean wind speeds were greater than $5 \mathrm{~m} \mathrm{~s}^{-1}$ from 200 to $360^{\circ}$. Data from these periods were filtered out. Flux data from TDLAS-TE were not affected by the strong winds as it was sheltered by TDLAS-LN for southwest to northerly wind directions, and data with winds against the side of TDLAS-TE were already filtered out due to tower interference (Fig. 1).

Cumulative gap-filled seasonal emission rates (planting to harvest) were calculated for each year. Daily mean emissions were estimated by extrapolating the mean of the available 30 min fluxes for each day to $\mathrm{g} \mathrm{N}_{2} \mathrm{O}-\mathrm{N} \mathrm{ha}^{-1}$. Linear interpolation was used to fill periods with missing data (Abalos et al., 2015).

Lag times $\left(t_{1}\right)$ for analyzers measuring $\mathrm{CO}_{2}$ concentration (TDLAS-TE when operated under dual-ramp mode; TDLAS-LN and EC155) were calculated using crosscorrelation such that $t_{1}$ was the time delay that maximized the covariance between the concentration and $w$ signals. $\mathrm{CO}_{2}$ concentrations were used for the $t_{1}$ calculation as the $\mathrm{N}_{2} \mathrm{O}$ signal was too weak for cross-correlations for the majority of time periods, as was also observed by Kroon et al. (2010a). This was determined on a day-by-day basis as the conditions that affected concentration signal delays (e.g., pump performance, filter clogging) remained relatively consistent on a daily timescale. For the daily lag value, $t_{1}$ was calculated for individual $30 \mathrm{~min}$ periods per day with the strongest $F_{\mathrm{CO}_{2}}$ as determined from raw 30 min flux values. An average of six lag times for each analyzer was used for a given day. Lag times ranged from 0.5 to $1.0 \mathrm{~s}$ for the TDLAS-TE and 0.6 to $1.2 \mathrm{~s}$ for the TDLAS-LN; $t_{1}$ for the EC155 was consistent at $0.1 \mathrm{~s}$. Processing delays in the sonic anemometer and the gas analyzers were subtracted from these lag times to calculate tube delays for comparison with $t_{\text {del }}$ derived from the frequency-response test. Values for $t_{1}$ derived from $t_{\text {del }}$ and sonic processing delays were used for periods when the TDLAS-TE was setup to measure only $\mathrm{N}_{2} \mathrm{O}$ concentrations.

The $\tau_{\mathrm{e}}$ derived from the frequency-response test was used to calculate corrections for high-frequency losses using the simplified formula given by Horst (1997):

$$
T_{r}=\frac{1}{1+\left(2 \pi n_{m} \frac{U}{z} \tau_{\mathrm{e}}\right)^{\alpha}},
$$

where $U$ is the mean wind speed, $z$ is the measurement height, and $n_{m}$ and $\alpha$ are constants determined from the idealized spectra of Kaimal et al. (1972) using values for unstable and stable conditions as presented by Horst (1997).

\subsection{Flux comparisons}

Half-hourly $F_{\mathrm{N}_{2} \mathrm{O}}$ and $F_{\mathrm{CO}_{2}}$ obtained with the two TDLAS were compared over the whole measurement period, and $F_{\mathrm{CO}_{2}}$ from both TDLASs was also compared to the EC155. Agreement was evaluated based on $r^{2}$ and slope of the linear regression between values from the different analyzers. Cumulative $F_{\mathrm{N}_{2} \mathrm{O}}$ over the measurement period for each TDLAS were calculated. No gap filling was applied to the time series, so totals do not represent absolute emissions for this site. Emissions were accumulated using only $30 \mathrm{~min} F_{\mathrm{N}_{2} \mathrm{O}}$ when data were available from both analyzers and converted from $n g \mathrm{~N}_{2} \mathrm{O}-\mathrm{N} \mathrm{m}^{-2} \mathrm{~s}^{-1}$ to $\mathrm{g} \mathrm{N}_{2} \mathrm{O}-\mathrm{N} \mathrm{ha}^{-1}$.

Random errors of each of the individual $30 \mathrm{~min} F_{\mathrm{N}_{2} \mathrm{O}}\left(\delta_{\mathrm{F}}\right)$ as measured by the TDLAS-LN and TDLAS-TE, were calculated using the filtering method of Salesky et al. (2012). This method was preferred over those requiring an estimate of the turbulent integral timescale (e.g., Finkelstein and Sims, 2001) as timescales can vary depending on definition (Dias et al., 2004). Salesky et al. (2012) showed that error estimates from the filtering method compared well to those using integral scales. Briefly, this method entailed repeatedly applying filters of increasing width $(\Delta t)$ to the high-frequency instantaneous fluxes from each $30 \mathrm{~min}$ period. Standard deviations of each set of filtered data were fit to $\Delta t^{-1 / 2}$. These successive power law fits were then fit to the entire averaging period to estimate the $30 \mathrm{~min} \delta_{\mathrm{F}}$. Propagation of $\delta_{\mathrm{F}}$ was then used to calculate the confidence intervals $(p=0.05)$ of the total cumulative $F_{\mathrm{N}_{2} \mathrm{O}}$ for the TDLAS-TE and TDLAS-LN time series.

Flux detection limits $(\delta F)$ were calculated using the method described in Blomquist et al. (2010) and Yang et al. (2016) where the detection limit is calculated using the instrument noise and the variability of the concentration signal:

$\delta F=\frac{2 \sigma_{w}}{\sqrt{T_{\mathrm{f}}}}\left[\sigma_{C_{\mathrm{a}}}^{2} \tau_{w \mathrm{c}}+\frac{\varphi C_{\mathrm{n}}}{4}\right]^{1 / 2}$,

such that $\sigma_{w}$ is the standard deviation of $w, T_{\mathrm{f}}$ is the fluxaveraging period, $\sigma_{C_{\mathrm{a}}}^{2}$ is the ambient variance of the concentration signal, $\tau_{w c}$ is the integral timescale for the ambient 
concentration variance, and $\phi_{C_{\mathrm{n}}}$ is the band-limited analyzer noise. $\phi_{C_{\mathrm{n}}}$ was calculated as the mean of the variance spectra from 1 to $5 \mathrm{~Hz}$. Values of $\sigma_{C_{\mathrm{a}}}^{2}$ were calculated as the second point of the autocovariance of the concentration signal (Yang et al., 2016). Blomquist et al. (2010) estimated $\tau_{\mathrm{wc}}$ using the peak frequency of the variance cospectrum. Peak frequencies here were modelled via the equation given in Horst (1997).

\section{Results}

\section{1 $\quad \mathrm{N}_{2} \mathrm{O}$ fluxes and data coverage}

Measurements of fluxes covered two growing seasons (May to October in 2015 and 2016), one post-harvest period (November to December 2015), winter (January to February 2016), and early spring (March to April 2016). Winter was classified as the period when nighttime temperatures were consistently below freezing. Figure 2 displays the mean daily air temperatures and precipitation for 2015 and 2016. Mean hourly air temperatures ranged from -26.1 to $31.6^{\circ} \mathrm{C}$. Winter of 2016 was on average $3{ }^{\circ} \mathrm{C}$ warmer than 30 -year normals and the maximum snow depth was relatively low at $8 \mathrm{~cm}$. Precipitation totals were close to 30 -year normal values for both years; however, May of 2015 received only $17 \mathrm{~mm}$ of rainfall until 31 May, which was considerably less than the normal amount of $89 \mathrm{~mm}$. Rainfall was lower than normal in May, June and July of 2016 with monthly totals $50 \%$ lower than the 30-year monthly normals.

Non-gap-filled mean daily $\mathrm{N}_{2} \mathrm{O}$ fluxes obtained with the TDLAS are shown in Fig. 3. One major $\mathrm{N}_{2} \mathrm{O}$ flux event occurred in 2015, one day after the first significant rainfall after planting and fertilizer application (8 and 9 June 2015, day of year (DOY) 159 and 160 in Fig. 3a). The daily mean 30 min $F_{\mathrm{N}_{2} \mathrm{O}}$ values for this event as measured by both analyzers were $600 \mathrm{ng} \mathrm{N}_{2} \mathrm{O}-\mathrm{N} \mathrm{m}^{-2} \mathrm{~s}^{-1}$ with the 30 min fluxes during the daytime and exceeding $800 \mathrm{ng} \mathrm{N}_{2} \mathrm{O}-\mathrm{N} \mathrm{m}^{-2} \mathrm{~s}^{-1}$ for several hours. Two subsequent post-fertilizer flux events occurred after rainfall on 16 and 28 June 2015 (DOY 167 and 179; Fig. 2a) and were smaller in magnitude with daily average fluxes of $100 \mathrm{ng} \mathrm{N}_{2} \mathrm{O}-\mathrm{N} \mathrm{m}^{-2} \mathrm{~s}^{-1}$. Throughout the remainder of the growing season of 2015 and post-harvest period of 2015 , mean daily fluxes were small and varied between -10 and $10 \mathrm{ng} \mathrm{N}_{2} \mathrm{O}-\mathrm{N} \mathrm{m}^{-2} \mathrm{~s}^{-1}$. The warmer-thanaverage winter in 2016 limited flux emissions from freezethaw processes that have been typically observed at this site (Furon et al., 2008; Risk et al., 2013; Abalos et al., 2015; Congreves et al., 2017; Wagner-Riddle et al., 2017) with average daily fluxes ranging from 0 to $30 \mathrm{ng} \mathrm{N}_{2} \mathrm{O}-\mathrm{N} \mathrm{m}^{-2} \mathrm{~s}^{-1}$ (Fig. 3b). The abnormally dry spring in 2016 prevented any significant $\mathrm{N}_{2} \mathrm{O}$ flux events associated with fertilizer application. Peak post-fertilizer daily flux values from 5 May to 13 June 2016 (DOY 126 to 165 in Fig. 3c) averaged $25 \mathrm{ng} \mathrm{N}_{2} \mathrm{O}-$ $\mathrm{N} \mathrm{m}^{-2} \mathrm{~s}^{-1}$. Daily flux values in the summer period of 2016 remained small $\left(\sim 5 \mathrm{ng} \mathrm{N}_{2} \mathrm{O}-\mathrm{Nm}^{-2} \mathrm{~s}^{-1}\right.$; Fig. 3c) but pre- dominantly positive throughout the summer. Mean gap-filled daily emissions as measured by each analyzer were averaged together. This gave total seasonal (planting to harvest) cumulative emissions of 3.34 and $1.20 \mathrm{~kg} \mathrm{~N}_{2} \mathrm{O}-\mathrm{N} \mathrm{ha}^{-1}$ for the growing seasons of 2015 and 2016, respectively. This is within the range of seasonal emissions typically observed at this site (Wagner-Riddle et al., 2007; Abalos et al., 2015) and represented a loss of 2.2 and $0.8 \%$ of the applied N.

Both analyzers performed well throughout the measurement period and maintenance requirements were minimal for both. Of the total number of $30 \mathrm{~min}$ periods for the whole measurement period, $44 \%$ of the 30 min flux values were filtered out due to low friction velocity, wind direction and footprint criteria, warnings from the sonic anemometer from precipitation, disruption from field operations, and power outages. Further filtering based on analyzer operation and diagnostics resulted in an additional removal of 16 (TDLAS-TE) and $28 \%$ (TDLAS-LN) of the fluxes due to equipment failure and periods of equipment reconfiguration. Longer data gaps occurred mostly for the TDLAS-LN due to pump malfunction, a faulty power supply, and an electronic module failure. Data outage for the TDLAS-TE in September 2015 was due to failure of the diaphragm pump providing bypass flow for the vortex intake before a model designed for long-term use was installed. Intermittent periods of data losses for both TDLASs also occurred when the enclosure temperature settings prevented the heaters from maintaining a constant temperature. This occurred at night during spring and fall periods when differences between daytime and nighttime temperatures were greatest and midday in the summer months when air temperatures exceeded $30^{\circ} \mathrm{C}$.

\subsection{Frequency-response test}

The in situ frequency-response test characterized the frequency response and tube delay for the three analyzers under the operating pressures tested. Impulse response peaks were at minimum $5 \mathrm{ppm}\left(\mathrm{N}_{2} \mathrm{O}\right)$ and $600 \mathrm{ppm}\left(\mathrm{CO}_{2}\right)$ above ambient concentrations. The peaks were consistent throughout each of the $20 \mathrm{~min}$ tests with an average coefficient of variation of $1.8 \%$. The precision of the impulse responses was further improved by averaging the 120 peaks in each test. Frequency-response curves for each analyzer obtained at the nominal cell pressure (Table 1) are given in Fig. 4. The frequency-response curve for the EC155 drops steeply at $5 \mathrm{~Hz}$ as expected due to its digital anti-aliasing filter. The effect of the digital filters is not distinctly visible for the $\mathrm{N}_{2} \mathrm{O}$ analyzers, but all three analyzers have little or no response at or near the Nyquist frequency $(10 \mathrm{~Hz})$, giving confidence that the frequency-response curves are not contaminated by aliasing. Table 2 contains the corresponding cutoff frequencies and effective time constants. The EC155 showed the best frequency response $\left(f_{\mathrm{c}}=4.05 \mathrm{~Hz}\right.$ and $\left.\tau_{\mathrm{e}}=39 \mathrm{~ms}\right)$ for $\mathrm{CO}_{2}$ (Table 2). The frequency response to $\mathrm{N}_{2} \mathrm{O}$ of TDLAS-TE was nearly as good as the EC155 ( $\left.f_{\mathrm{c}}=3.5 \mathrm{~Hz}, \tau_{\mathrm{e}}=45 \mathrm{~ms}\right)$, while 


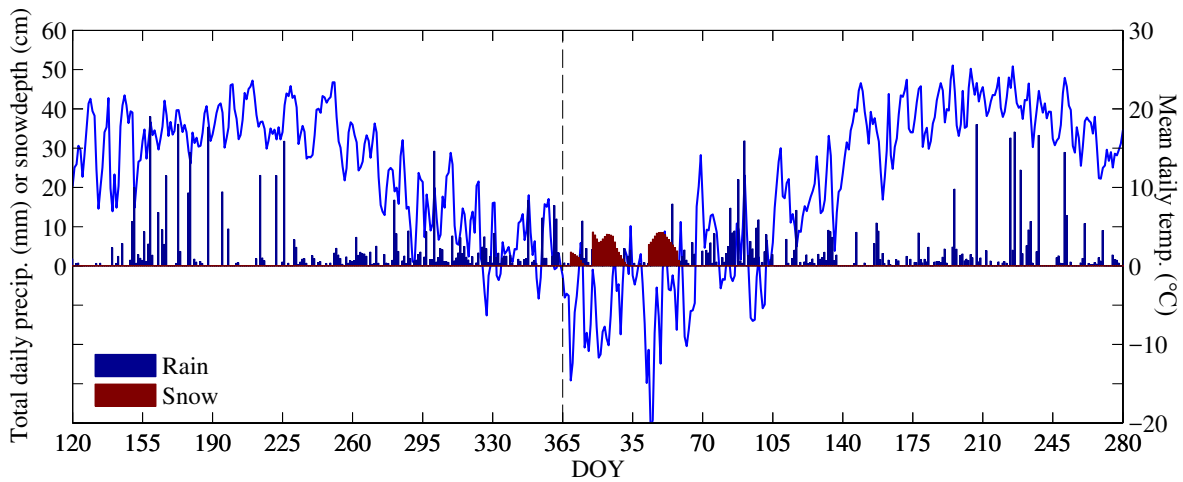

Figure 2. Daily precipitation and temperature for 2015 and 2016. Rain values (mm) are the total rainfall per day, and snow values (cm) are the depth of snow present.

Table 2. Analyzer frequency-response characteristics from this study and that of Rannik et al. (2015). Residence times ( $\left.\tau_{\text {res }}\right)$ were calculated from values given in Table 1. $f_{\mathrm{c}, \mathrm{t}}$ is the theoretical best-case cutoff frequency, assuming no mixing for the single-pass sample cells and complete mixing for the multi-pass sample cells, and $\tau_{\mathrm{e}, \mathrm{t}}$ is the corresponding effective time constant. $f_{\mathrm{c}}$ and $\tau_{\mathrm{e}}$ are results from the impulse response test. Results $\left(\tau_{\mathrm{e}, \mathrm{s}}\right.$ and $f_{\mathrm{c}, \mathrm{s}}$ ) from Rannik et al. (2015) were derived from cospectral analyses. The tube delays $t_{\mathrm{del}}$ are the measured total delay minus the processing delay. Time constants and $t_{\mathrm{del}}$ are in units of milliseconds and cutoff frequencies are in hertz.

\begin{tabular}{lrrrrrr}
\hline & $\tau_{\text {res }}$ & $f_{\mathrm{c}, \mathrm{t}}$ & $\tau_{\mathrm{e}, \mathrm{t}}$ & $f_{\mathrm{c}}$ & $\tau_{\mathrm{e}}$ & $t_{\mathrm{del}}$ \\
\hline Current study & & & & & & \\
\hline TDLAS-LN & 114 & 3.88 & 41 & 2.30 & 69 & 720 \\
TDLAS-TE & 48 & 9.22 & 17 & - & - & - \\
TDLAS-TE (vortex) & 108 & 4.10 & 39 & 3.50 & 45 & 578 \\
EC155 & 54 & 8.19 & 19 & 4.05 & 39 & 100 \\
\hline From Rannik et al. (2015) & & & & $f_{\mathrm{c}, \mathrm{s}}$ & $\tau_{\mathrm{e}, \mathrm{s}}$ & \\
\hline TGA100A (Campbell Scientific Inc.) & $100^{\mathrm{a}}$ & 4.42 & 36 & 1.33 & 120 & - \\
CW-TILDAS-CS (Aerodyne Research Inc.) & 119 & 1.34 & 119 & 2.27 & 70 & - \\
N2O/CO-23d (Los Gatos Research Inc.) & 244 & 0.65 & 244 & 0.61 & 260 & - \\
QC-TILDAS76-CS (Aerodyne Research Inc.) & 116 & 1.37 & 116 & $1.99 / 0.94^{\mathrm{b}}$ & $80 / 150^{\mathrm{b}}$ & - \\
\hline
\end{tabular}

a Assumes $15 \%$ of flow is used for purge. ${ }^{\mathrm{b}}$ Calculated with $\mathrm{CO}_{2}$

TDLAS-LN showed lower-frequency response $\left(f_{\mathrm{c}}=2.3 \mathrm{~Hz}\right.$ and $\left.\tau_{\mathrm{e}}=69 \mathrm{~ms}\right)$. TDLAS-LN measured both $\mathrm{N}_{2} \mathrm{O}$ and $\mathrm{CO}_{2}$ during the frequency-response test; results for $\mathrm{CO}_{2}$ were identical to those for $\mathrm{N}_{2} \mathrm{O}$ (data not shown). These measured $f_{\mathrm{c}}$ were used in Eq. 1 to calculate $T_{\mathrm{FR}}$, which are shown for comparison in Fig. 4. Spectral losses (Eq. 7) calculated with the $f_{\mathrm{c}}$ were on average $5 \%$ of the measured flux for the TDLAS-TE and $7 \%$ for the TDLAS-LN. All measured $f_{\mathrm{c}}$ values were lower than the best-case theoretical cutoff frequencies $\left(f_{\mathrm{c}, \mathrm{t}}\right)$ calculated from $\tau_{\text {res }}$ (Table 2), indicating some attenuation of high frequencies in the sampling system components and sample cells, as expected. Frequency responses for both $\mathrm{N}_{2} \mathrm{O}$ analyzers were tested at a range of pressures as varying field conditions can cause pressures to drift with pump performance and, in the case of TDLAS$\mathrm{LN}$, filter clogging. The TDLAS-LN $f_{\mathrm{c}}$ increased significantly with pressure $(1.1 \mathrm{~Hz}$ at $29 \mathrm{mb}$ to $2.3 \mathrm{~Hz}$ at $58 \mathrm{mb})$, whereas the response of the TDLAS-TE showed less varia- tion $(3.1 \mathrm{~Hz}$ at $28 \mathrm{mb}$ to $3.65 \mathrm{~Hz}$ at $43 \mathrm{mb}$; data not shown). Response times calculated using measured cospectra are included in the Supplement.

Tube delays determined from the impulse responses at the nominal cell pressure for the three analyzers are given in Table 2. As expected, the EC155 had the shortest $t_{\mathrm{del}}$ at $100 \mathrm{~ms}$. The tube delay of TDLAS-TE was longer $(578 \mathrm{~ms})$ due to the greater tubing length and lower flow rate. The tube delay for TDLAS-LN was longest at $720 \mathrm{~ms}$, despite its higher flow rate, due to the larger volumes for its tubing, filter, and dryer. Tube delays for the $\mathrm{N}_{2} \mathrm{O}$ analyzers over the range of operating pressures showed a decrease in $t_{\text {del }}$ with increasing cell pressure (Fig. 5). Decreases in flow rate with pressure for TDLAS-LN acted to increase $t_{\text {del }}$ to a greater degree than for the TDLAS-TE. Tube delays determined from the crosscorrelation of $\mathrm{CO}_{2}$ with $w$ ranged from 650 to $1450 \mathrm{~ms}$ for TDLAS-LN and 550 to $1050 \mathrm{~ms}$ for TDLAS-TE and were 

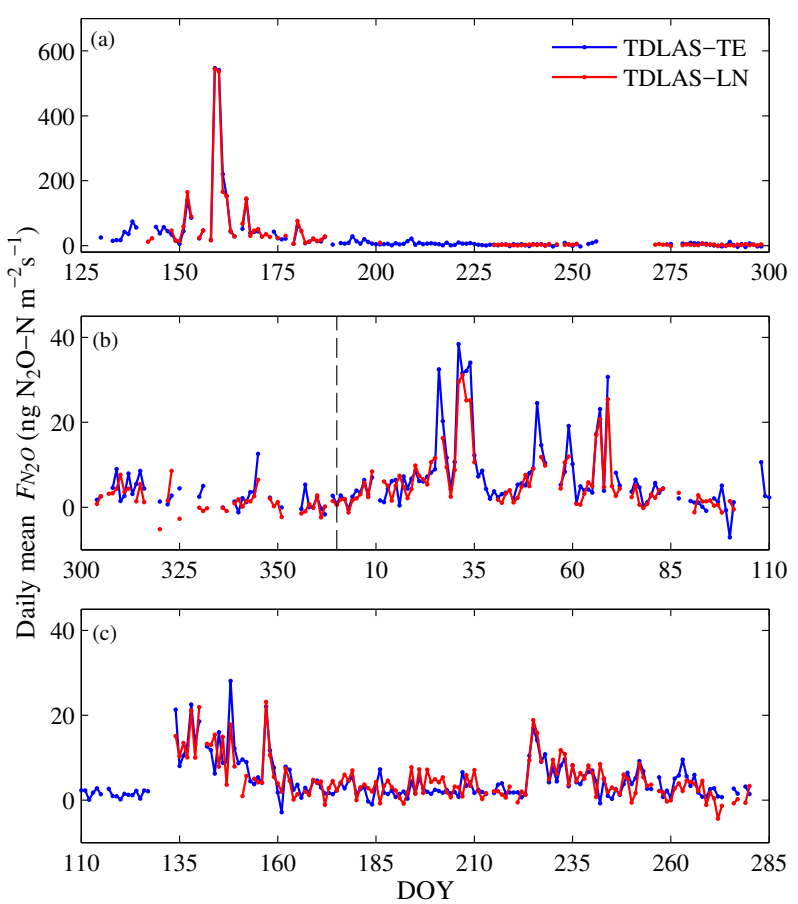

Figure 3. Mean daily fluxes of $\mathrm{N}_{2} \mathrm{O}-\mathrm{N}$ measured by each analyzer. Panel (a) shows the period of high $\mathrm{N}_{2} \mathrm{O}$ fluxes in the postfertilization period of 2015 and the fluxes measured throughout the growing season. Panel (b) shows the fluxes measured during the post-harvest period of 2015 and winter of 2016. The dotted line in panel (b) demarcates the separation between years 2015 and 2016. Panel (c) shows fluxes measured from early spring to the end of the growing season of 2016 .

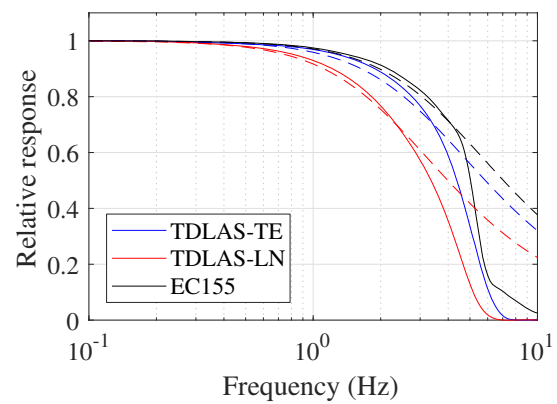

Figure 4. Results of the frequency-response test of TDLAS-LN and TDLAS-TE for $\mathrm{N}_{2} \mathrm{O}$ and the EC155 $\left(\mathrm{CO}_{2}\right)$ under normal operating conditions (solid lines); dashed lines are modelled $T_{\mathrm{FR}}$ calculated using the measured $f_{\mathrm{c}}$ in Eq. (1).

consistent with those determined from the impulse response (Fig. 5).

\subsection{Flux comparison}

Comparison of $F_{\mathrm{N}_{2} \mathrm{O}}$ showed similar values for both TDLASs on short and long timescales. Figure 6a shows the agreement between $30 \mathrm{~min} \quad F_{\mathrm{N}_{2} \mathrm{O}}$ values measured

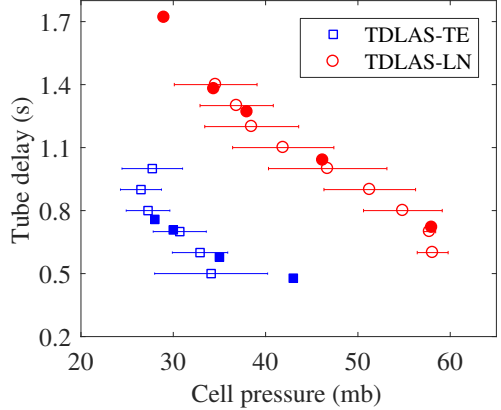

Figure 5. Tube delay $\left(t_{\mathrm{del}}\right)$ determined from the frequency-response test (solid symbols) and from the cross-correlation between the $\mathrm{CO}_{2}$ and $w$ (open symbols) across the range of operating pressures. Error bars are the standard deviation of the mean cell pressure associated with each value.

by each analyzer $\left(r^{2}=0.97\right.$, slope $\left.=1.01\right)$. The majority $(86 \%)$ of $30 \mathrm{~min} \mathrm{~N}_{2} \mathrm{O}$ fluxes were small and below $20 \mathrm{ng} \mathrm{N}_{2} \mathrm{O}-\mathrm{N} \mathrm{m}^{-2} \mathrm{~s}^{-1}$. The general correspondence between the TDLAS-LN and TDLAS-TE flux values remained for the small flux values (Fig. 6b). Scatter in the low $F_{\mathrm{N}_{2} \mathrm{O}}$ (Fig. 6b) was related to instrument noise. Both analyzers showed excellent agreement with the $\mathrm{CO}_{2}$ fluxes measured using the EC155. The slope and correlation coefficient of the linear regression between the EC155 and TDLAS-TE were, respectively, 1.03 and 0.998 (Fig. 6c). Similarly, the slope and correlation coefficient of the linear regression between the EC155 and TDLAS-LN were 1.03 and 0.998 (data not shown).

Figure 7 shows the mean variance spectra of the $\mathrm{N}_{2} \mathrm{O}$ signals from each TDLAS analyzer for a period of 10 days where no $\mathrm{N}_{2} \mathrm{O}$ fluxes were observed (29 June to 9 July 2016). The variance spectra of both analyzers were dominated by instrument noise as $\mathrm{N}_{2} \mathrm{O}$ emissions were at background levels. Values of $\phi_{C_{\mathrm{n}}}$ were $0.28 \mathrm{ppb}^{2} \mathrm{~Hz}^{-1}$ for the TDLASTE and $0.22 \mathrm{ppb}^{2} \mathrm{~Hz}^{-1}$ for the TDLAS-LN. When considering only instrument noise, detection limits with mean conditions of $U=3.5 \mathrm{~m} \mathrm{~s}^{-1}, z=4 \mathrm{~m}$, and $\sigma_{w}=0.5 \mathrm{~m} \mathrm{~s}^{-1}$ were $6.6 \mathrm{ng} \mathrm{N}_{2} \mathrm{O}-\mathrm{N} \mathrm{m}^{-2} \mathrm{~s}^{-1}$ for the TDLAS-TE and $5.2 \mathrm{ng} \mathrm{N}_{2} \mathrm{O}$ $\mathrm{N} \mathrm{m}^{-2} \mathrm{~s}^{-1}$ for the TDLAS-LN. Incorporating signal noise increased $\delta F_{\mathrm{N}_{2} \mathrm{O}}$ to $9.9 \mathrm{ng} \mathrm{N}_{2} \mathrm{O}-\mathrm{N} \mathrm{m}^{-2} \mathrm{~s}^{-1}$ for the TDLAS-TE and $19.6 \mathrm{ng} \mathrm{N}_{2} \mathrm{O}-\mathrm{N} \mathrm{m}^{-2} \mathrm{~s}^{-1}$ for the TDLAS-LN. Despite the lower instrument noise, concentration signals of the TDLASLN were less steady than the TDLAS-TE during the period evaluated ( $\sigma_{C_{\mathrm{a}}}^{2}$ of 0.27 and $0.042 \mathrm{ppb}^{2}$, respectively).

Emissions were accumulated over the measurement period to evaluate the long-term comparison of the total $F_{\mathrm{N}_{2} \mathrm{O}}$ (Fig. 8). No gap filling was applied for the comparison of cumulated sums between analyzers. From planting of 2015 to harvest of 2016, TDLAS-TE measured total emissions of $1247 \pm 11.3 \mathrm{~g} \mathrm{~N}_{2} \mathrm{O}-\mathrm{N} \mathrm{ha}^{-1}$ and TDLAS-LN measured $1272 \pm 9.3 \mathrm{~g} \mathrm{~N}_{2} \mathrm{O}-\mathrm{N} \mathrm{ha}^{-1}$, where uncertainties are the propagated random errors. 

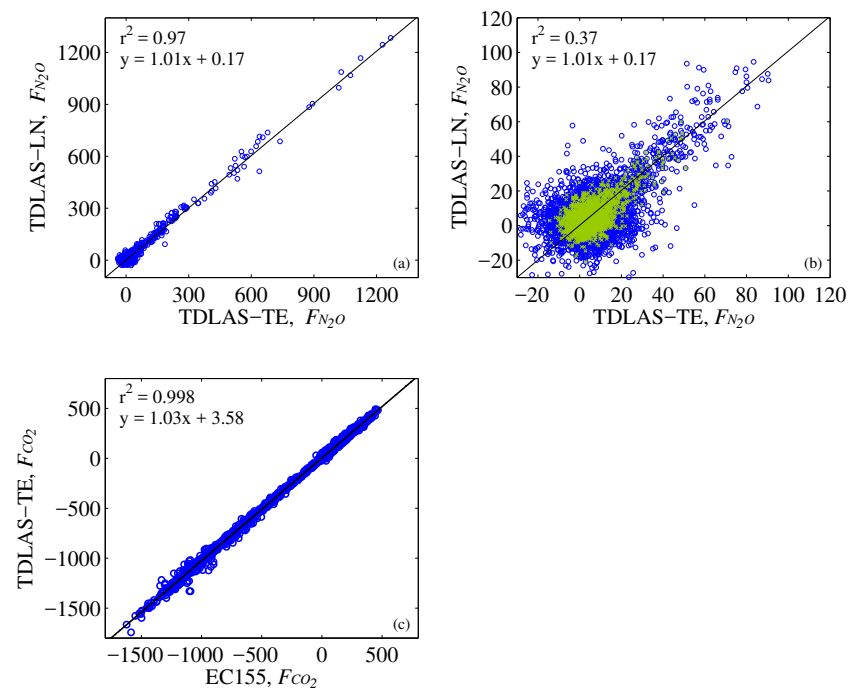

Figure 6. Comparison of $30 \mathrm{~min}$ fluxes measured by each analyzer. Panel (a) displays the comparison of $\mathrm{N}_{2} \mathrm{O}-\mathrm{N}$ fluxes $\left(\mathrm{ng} \mathrm{N}_{2} \mathrm{O}-\right.$ $\mathrm{N} \mathrm{m}^{-2} \mathrm{~s}^{-1}$ ) for the entire data set, panel (b) shows the same $\mathrm{N}_{2} \mathrm{O}-\mathrm{N}$ flux data set ( $\mathrm{ng} \mathrm{N}_{2} \mathrm{O}-\mathrm{N} \mathrm{m}^{-2} \mathrm{~s}^{-1}$ ) but centred on the low flux values. The green " $x$ " markers in panel (b) are the fluxes measured when the standard deviation of background $\mathrm{N}_{2} \mathrm{O}$ concentrations for both analyzers was less than $2 \mathrm{ppb} \mathrm{N}_{2} \mathrm{O}$. Panel (c) is the comparison of $\mathrm{F}_{\mathrm{CO}_{2}}$ between TDLAS-TE and EC155 $\left(\mu \mathrm{g} \mathrm{CO} \mathrm{m}^{-2} \mathrm{~s}^{-1}\right)$.

\section{Discussion}

Both $\mathrm{N}_{2} \mathrm{O}$ analyzers were well suited for the long-term and continuous measurement of $F_{\mathrm{N}_{2} \mathrm{O}}$ that are required to fully capture the temporal dynamics of $\mathrm{N}_{2} \mathrm{O}$ emissions (Savage et al., 2014; Shurpali et al., 2016). Both operated continuously for over 1.5 years through the various environmental conditions encountered in Southern Ontario. Data gaps were caused by problems with sample pumps, a power supply failure, and from reconfigurations for the intercomparison experiment, (e.g., frequency-response testing, swapping lasers, and reconfiguring the sampling systems). Disregarding these time periods, data coverage of $56 \%$ was typical for EC measurements at that site after typical EC filtering for rainy periods, low wind speeds, and wind direction (Santos et al., 2011; Brown et al., 2013). Further steps can be taken to reduce data losses attributable to the TDLAS operation, including adjusting the analyzer's internal-temperature set point more frequently (seasonally to monthly) and protecting the analyzer from strong winds. A simple baffle the height of the analyzer $(0.55 \mathrm{~m})$ along the side of the analyzer facing the mean wind direction would provide sufficient shelter from strong winds $\left(U>5 \mathrm{~m} \mathrm{~s}^{-1}\right)$.

The older TDLAS-LN system required periodic maintenance including liquid nitrogen fills (twice weekly), replacing filter elements (twice monthly), and changing pump oil (monthly). The TDLAS-TE system with the vortex intake and dry scroll pump required no routine maintenance. The

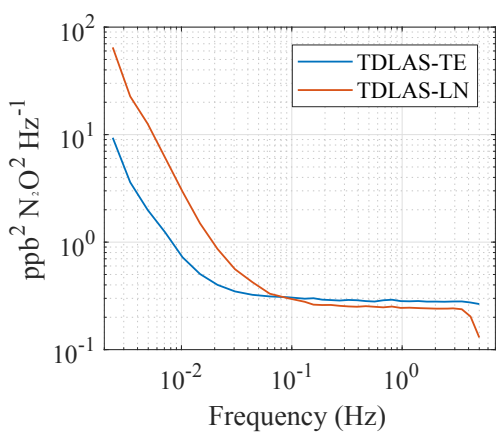

Figure 7. Mean $\mathrm{N}_{2} \mathrm{O}$ variance spectra of each TDLAS analyzer from 29 June to 9 July 2016.

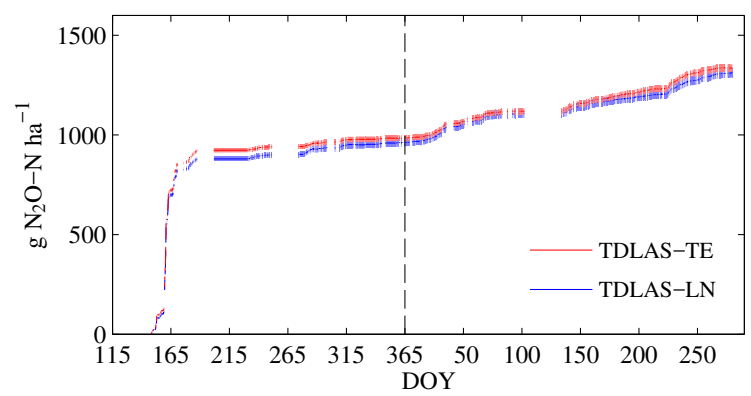

Figure 8. Cumulative (not gap-filled) $\mathrm{N}_{2} \mathrm{O}-\mathrm{N}$ emissions. Shaded areas represent the $p=0.05$ confidence intervals calculated using the random error calculations.

TDLAS-TE also operated using less power for the sample pump than the TDLAS-LN (250 W versus $950 \mathrm{~W})$. The ruggedness and low maintenance of TDLAS-TE through all seasons showed the suitability of the analyzer for capturing post-fertilizer and freeze-thaw emissions.

The TDLAS-TE system, with smaller sample-cell volume, single-tube dryer, and vortex intake had better frequency response $\left(f_{\mathrm{c}}=3.5 \mathrm{~Hz}\right)$ than the TDLAS-LN system $\left(f_{\mathrm{c}}=2.30 \mathrm{~Hz}\right)$, while operating at lower flow rates $(3.5 \mathrm{com}$ pared to $14.5 \mathrm{~L} \mathrm{~min}^{-1}$ ) and with lower sample pump power consumption. The TDLAS-TE cutoff frequency of $3.5 \mathrm{~Hz}$ was only slightly lower than that of the short-tubed EC155 closed-path analyzer $\left(f_{\mathrm{c}}=4.05 \mathrm{~Hz}\right)$. The frequency response of the TDLAS-TE system was affected less by changes in pressure and flow rate than the TDLAS-LN, which helped to maintain constancy of $f_{\mathrm{c}}$ with the slight variations in pressure that occur during long-term field operations. The frequency response of TDLAS-LN was still adequate for EC measurements (McBean, 1972; Eugster et al., 2007). Rannik et al. (2015) reported EC system time constants calculated from cospectra $\left(\tau_{\mathrm{e}, \mathrm{s}}\right)$ for several $\mathrm{N}_{2} \mathrm{O}$ analyzers, which are summarized in Table 2. The same model $\mathrm{N}_{2} \mathrm{O}$ analyzer (TGA100A) with a similar sampling system at similar flow $\left(17 \mathrm{~L} \mathrm{~min}^{-1}\right)$ and pressure $(50 \mathrm{mb})$ had a $\tau_{\mathrm{e}, \mathrm{s}}$ of $120 \mathrm{~ms}$. The lower $\tau_{\mathrm{e}}$ in this study $(69 \mathrm{~ms})$ is likely related to the shorter tube and newer lower-volume filter holder as com- 
pared to the higher-volume filter holder used in the Rannik et al. (2015) study or discrepancies between our direct frequency-response assessment compared to deriving $\tau_{\mathrm{e}}$ from cospectral analyses. Rannik et al. (2015) found a disagreement of almost a factor of 2 in the $\mathrm{N}_{2} \mathrm{O}$ and $\mathrm{CO}_{2}$ time constants for a system that measured both gases, opting to use the value measured for $\mathrm{CO}_{2}$ for spectral corrections of both gases. However, it is difficult to directly compare the absolute values of the frequency-response $\tau_{\mathrm{e}}$ with the commonly used cospectra method (Detto et al., 2011; Peltola et al., 2014; Rannik et al., 2015; Aubinet et al., 2016). The cospectral method is highly dependent on the adherence of the spectra to similarity scaling and is also affected by sensor separation and by imperfect synchronization of the scalar with vertical wind. The frequency-response test provided a direct assessment of sampling system response times, as it eliminates the possibility of response times being affected by artefacts of the temperature or $w$ spectra.

Analyzer sample cell and sampling system design both have an impact on system frequency response. Multi-pass sample cells tend to be much shorter but with larger diameters compared to single-pass sample cells; therefore, the air flow tends to behave as a mixing volume. Measured $\tau_{\mathrm{e}}$ for analyzers with multi-pass sampling cells are generally greater than the $\tau_{\text {res }}$ of the sample cell. Nelson et al. (2004) directly measured the frequency response of an analyzer with a multipass sample cell using an exponential fit to measurements of a step change in concentration. Their $\tau_{\mathrm{e}}$ of $63 \mathrm{~ms}$ was slightly greater than the theoretical time constant $\left(\tau_{\text {res }}=54 \mathrm{~ms}\right)$. Neftel et al. (2010) measured the time constant for an EC system with a similar sample cell using the same step-change technique. The measured $\tau_{\mathrm{e}}$ of $400 \mathrm{~ms}$ was more than twice the theoretical time constant $\left(\tau_{\text {res }}=175 \mathrm{~ms}\right)$ of the sample cell, likely due to the long tube $(30 \mathrm{~m})$ and other sampling components. Single-pass sample cells, which tend to be long and narrow, have less mixing as the air flows through the cell, giving them a theoretical advantage of a factor of 2.78 compared to multi-pass sample cells. The TDLAS-TE $\tau_{\mathrm{e}}$ was within $15 \%$ of this theoretical $\tau_{\mathrm{e}, \mathrm{t}}$, indicating near ideal performance in the sample cell and sampling system. The EC155 $\tau_{\mathrm{e}}$ was a factor of 2 larger than the theoretical $\tau_{\mathrm{e}, \mathrm{t}}$. This is likely due to mixing in the sample cell, which has a length/diameter ratio of 15 , compared to 110 for the TDLAS-TE. TDLAS-LN has a diameter/length ratio of 75 , suggesting its performance should also approach the ideal. However, the TDLAS-LN $\tau_{\mathrm{e}}$ was $40 \%$ greater than $\tau_{\mathrm{e}, \mathrm{t}}$, compared to $15 \%$ for TDLAS-TE. This additional frequencyresponse degradation was most likely caused by attenuation in the multi-tube dryer. Ratios of $\tau_{\mathrm{e}} / \tau_{\mathrm{e}, \mathrm{t}}$ from similar analyzers operating without driers (Table 2) were comparable to those of the TDLAS-LN and TDLAS-TE systems, although not directly as spectral calculations of $\tau_{\mathrm{e}}$ were used in that study.

Operating the $\mathrm{N}_{2} \mathrm{O}$ systems with driers prevented uncertainties from spectroscopic and density corrections. Improper application of the WPL (Webb-Pearman-Leuning) corrections, as well as variations in flux processing steps, can affect flux values (Aubinet et al., 2012; Mammarella et al., 2016). For fluxes close to zero, WPL corrections for fluctuations in water vapour can be greater than the value of the scalar flux, and uncertainty of the correction can be of similar magnitude to the small fluxes (Detto et al., 2011). Line broadening caused by moisture in the sample can also cause significant errors in $F_{\mathrm{N}_{2} \mathrm{O}}$ (Neftel et al., 2010).

Lag times can be difficult to determine using crosscorrelation methods on data with weak signals, which is often the case for $\mathrm{N}_{2} \mathrm{O}$ (Pihlatie et al., 2005; Neftel et al., 2010). Inaccurate lag times can lead to underestimations of flux values. The $t_{\text {del }}$ from the impulse response tests corresponded well with the $t_{1}$ obtained for $\mathrm{CO}_{2}$ using the crosscorrelation method. The $t_{\text {del }}$ measured with the impulse response method reduced uncertainty in the $\mathrm{N}_{2} \mathrm{O}$ lag times used in the flux processing in the absence of a $\mathrm{CO}_{2}$ signal. This approach is useful for long-term studies measuring agricultural $\mathrm{N}_{2} \mathrm{O}$ fluxes when signals are too weak for automatic covariance maximization and when variations in operating conditions preclude the use of a constant lag value. Tube delay of the TDLAS-TE $(0.6 \mathrm{~s}$ at $35 \mathrm{mb})$ was lower than that of the TDLAS-LN $(0.8 \mathrm{~s}$ at $58 \mathrm{mb})$, showing the improved transit time of the upgraded intake system. These values were comparable to tube delay values of analyzers operated without driers (Rannik et al., 2015), showing how the TDLAS systems used here (with driers) could be optimized for fast response, while also avoiding corrections associated with lack of air drying.

\section{Conclusions}

The field trial of the new TDLAS-TE analyzer with the optimized sampling system consisting of a vortex intake, singletube drier, and lower-power pump demonstrated the ability of this analyzer to operate continuously through several field seasons with minimal maintenance with the frequency response needed for EC measurements. The frequency response was comparable to that of a short-tubed $\mathrm{CO}_{2} \mathrm{EC}$ system and was better than published reports of $\mathrm{N}_{2} \mathrm{O}$ EC systems operating without driers.

The legacy TDLAS-LN analyzer presented a lower cutoff frequency and higher tube delay than the TDLAS-TE and EC155 but showed improvement over previous reports due to the use of a shorter intake tube and a lower volume filter holder. The $30 \mathrm{~min} F_{\mathrm{CO}_{2}}$ and $F_{\mathrm{N}_{2} \mathrm{O}}$ values measured by the TDLAS systems compared well; $F_{\mathrm{CO}_{2}}$ values measured by these systems were also comparable with the EC155.

More studies of long-term, multi-season $\mathrm{N}_{2} \mathrm{O}$ fluxes are needed to improve global estimates of agricultural $\mathrm{N}_{2} \mathrm{O}$ emissions (Reay et al., 2012; Wagner-Riddle et al., 2017). The optimal performance combined with its lower power and low maintenance requirements make the TDLAS-TE suitable 
for $\mathrm{N}_{2} \mathrm{O}$ flux measurements under rugged field conditions in remote or rural areas where power quality can be a concern.

Data availability. Any persons requiring the dataset can request it by contacting the authors.

\section{The Supplement related to this article is available online at https://doi.org/10.5194/amt-11-1583-2018-supplement.}

Competing interests. Steve Sargent is employed by Campbell Scientific Inc., the manufacturer of several instruments mentioned in this study.

Acknowledgements. This work was funded by the Natural Science and Engineering Research Council of Canada and Fertilizer Canada. Technical support was provided by Sean Jordan.

Edited by: Christian Brümmer

Reviewed by: Mingxi Yang and two anonymous referees

\section{References}

Abalos, D., Brown, S. E., Vanderzaag, A. C., Gordon, R. J., Dunfield, K. E., and Wagner-Riddle, C.: Micrometeorological measurements over 3 years reveal differences in $\mathrm{N}_{2} \mathrm{O}$ emissions between annual and perennial crops, Glob. Change Biol., 3, 1244$1255,2015$.

Aubinet, M., Grelle, A., Ibrom, A., Rannik, Ü., Moncrieff, J., Foken, T., Kowalski, A., Martin, P., Berbigier, P., Bernhofer, C., Clement, R., Elbers, J., Granier, A., Grünwald, T., Morgenstern, K., Pilegaard, K., Rebmann, C., Snijders, W., Valentini, R., and Vesala, T.: Estimates of the annual net carbon and water exchange of forests: The EUROFLUX methodology, Adv. Ecol. Res., 30, 113-175, https://doi.org/10.1016/S00652504(08)60018-5, 2000.

Aubinet, M., Vesala, T., and Papale, D. (Eds.): Eddy Covariance: A Practical Guide to Measurement and Data Analysis, Springer, 2012.

Aubinet, M., Joly, L., Loustau, D., De Ligne, A., Chopin, H., Cousin, J., Chauvin, N., Decarpenterie, T., and Gross, P.: Dimensioning IRGA gas sampling systems: laboratory and field experiments, Atmos. Meas. Tech., 9, 1361-1367, https://doi.org/10.5194/amt-9-1361-2016, 2016.

Blomquist, B. W., Huebert, B. J., Fairall, C. W., and Faloona, I. C.: Determining the sea-air flux of dimethylsulfide by eddy correlation using mass spectrometry, Atmos. Meas. Tech., 3, 1-20, https://doi.org/10.5194/amt-3-1-2010, 2010.

Brown, S. E., Warland, J. S., Santos, E., Wagner-Riddle, C., Staebler, R. M., and Wilton, M.: Estimating a Lagrangian length scale using measurements of $\mathrm{CO}_{2}$ in a plant canopy, Bound.-Lay. Meteorol., 147, 83-102, 2013.
Burba, G. G., McDermittt, D. K., Anderson, D. J., Furtaw, M. D., and Eckles, R.: Novel design of an enclosed $\mathrm{CO}_{2} / \mathrm{H}_{2} \mathrm{O}$ gas analyser for eddy covariance flux measurements, Tellus B, 62, 743748, 2010.

Congreves, K., Brown, S., Nemeth, D., Dunfield, K., and WagnerRiddle, C.: Differences in field-scale $\mathrm{N}_{2} \mathrm{O}$ flux linked to crop reside removal under two tillage systems in cold climates, GCB Bioenergy, 9, 666-680, https://doi.org/10.1111/gcbb.12354, 2017.

Davidson, E. A.: The contribution of manure and fertilizer nitrogen to atmospheric nitrous oxide since 1860 , Nat. Geosci., 2, 659662, 2009.

Detto, M., Verfaillie, J., Anderson, F., Xu, L., and Baldocchi, D.: Comparing laser-based open- and closed-path gas analyzers to measure methane fluxes using the eddy covariance method, Agr. Forest Meteorol., 151, 1312-1324, 2011.

Dias N., Chamecki M., Kan A., and Okawa C.: A study of spectra, structure and correlation functions and their implications for the stationarity of surface-layer turbulence, Bound.-Lay. Meteorol., 110, 165-189, 2004.

Edwards, G., Thurtell, G., Kidd, G., Dias, G., and Wagner-Riddle, C.: A diode laser based gas monitor suitable for measurement of trace gas exchange using micrometeorological techniques, Agr. Forest Meteorol., 115, 71-89, 2003.

Eugster, W., Zeyer, K., Zeeman, M., Michna, P., Zingg, A., Buchmann, N., and Emmenegger, L.: Methodical study of nitrous oxide eddy covariance measurements using quantum cascade laser spectrometery over a Swiss forest, Biogeosciences, 4, 927-939, https://doi.org/10.5194/bg-4-927-2007, 2007.

Finkelstein, P. L. and Sims, P. F.: Sampling error in eddy correlation flux measurements, J. Geophys. Res., 106, 3503-3509, 2001.

Flechard, C., Ambus, P., Skiba, U., Rees, R., Hensen, A., Van Amstel, A., van den Pol-van Dasselaar, A., Soussana, J.-F., Jones, M., Clifton-Brown, J., Raschi, A., Horvath, L., Neftel, A., Jocher, M., Ammann, C., Leifeld, J., Fuhrer, J., Calanca, P. L., Thalman, E., Pilegaard, K., Marco, C., Campbell, C., Nemitz, E., Hargreaves, K., Levy, P., Ball, B., Jones, S., van de Bulk, W., Groot, T., Blom, M., Domingues, R., Kasper, G., Allard, V., Ceschia, E., Cellier, P., Laville, P., Henault, C., Bizouard, F., Abdalla, M., Williams, M., Baronti, S., Berretti, F., and Grosz, B.: Effects of climate and management intensity on nitrous oxide emissions in grassland systems across Europe, Agr. Ecosyst. Environ., 121, 135-152, 2007.

Furon, A. C., Wagner-Riddle, C., Smith, C. R., and Warland, J. S.: Wavelet analysis of wintertime and spring thaw $\mathrm{CO}_{2}$ and $\mathrm{N}_{2} \mathrm{O}$ fluxes from agricultural fields, Agr. Forest Meteorol., 148, 13051317, 2008.

Groffman, P. M., Butterbach-Bahl, K., Fulwieler, R. W., Gold, A. J., Morse, J. L., Stander, E. K., Tague, C., Tonitto, C., and Vidon, P.: Challenges to incorporating spatially and temporally explicit phenomena (hotspots and hot moments) in denitrification models, Biogeochemistry, 93, 49-77, 2009.

Horst, T. W.: A simple formula for attenuation of eddy fluxes measured with first-order- response scalar sensors, Bound.-Lay. Meteorol., 82, 219-233, 1997.

Huang, H., Wang, J., Hui, D., Miller, D. R., Bhattarai, S., Dennis, S., Smart, D., Sammis, T., and Reddy, K. C.: Nitrous oxide emissions from a commercial cornfield (Zea mays) measured using 
the eddy covariance technique, Atmos. Chem. Phys., 14, 1283912854, https://doi.org/10.5194/acp-14-12839-2014, 2014.

Ibrom, A., Dellwik, E., Flyvbjerg, H., Jensen, N. O., and Pilegaard, K.: Strong low-pass filtering effects on water vapor flux measurements with closed-path eddy correlation systems, Agr. Forest Meteorol., 147, 140-156, 2007.

IPCC: Climate Change: The Physical Science Basis. Contribution of Working Group I to the Fifth Assessment Report of the Intergovernmental Panel on Climate Change, Cambridge University Press, Cambridge, United Kingdom and New York, USA, 2013.

Jones, S. K., Famulari, D., Di Marco, C. F., Nemitz, E., Skiba, U. M., Rees, R. M., and Sutton, M. A.: Nitrous oxide emissions from managed grassland: a comparison of eddy covariance and static chamber measurements, Atmos. Meas. Tech., 4, 21792194, https://doi.org/10.5194/amt-4-2179-2011, 2011.

Kaimal, J. and Finnigan, J. J.: Atmospheric Boundary Layer Flows: Their Structure and Measurement, Oxford University Press, New York, USA, 304 pp., 1994.

Kaimal, J. C., Wyngaard, J. C., Izumi, Y., and Cote, O. R.: Spectral characteristics of surface-layer turbulence, Q. J. Roy. Meteor. Soc., 98, 563-589, 1972.

Kroon, P., Hensen, A., Jonker, H., Ouwersloot, H., Vermeulen, A., and Bosveld, F.: Uncertainties in eddy covariance flux measurements assessed from $\mathrm{CH}_{4}$ and $\mathrm{N}_{2} \mathrm{O}$ observations, Agr. Forest Meteorol., 150, 806-816, 2010a.

Kroon, P., Schuitmaker, A., Jonker, H., Tummers, M., Hensen, A., and Bosveld, F.: An evaluation by laser Doppler anemometry of the correction algorithm based on Kaimal cospectra for high frequency losses of EC flux measurements of $\mathrm{CH}_{4}$ and $\mathrm{N}_{2} \mathrm{O}$, Agr. Forest Meteorol., 150, 794-805, 2010b.

Leuning, R. and Judd, M. J.: The relative merits of open- and closed-path analysers for measurement of eddy fluxes, Glob. Change Biol., 2, 241-253, 1996.

Ma, J., Zha, T., Jia, X., Sargent, S., Burgon, R., Bourque, C. P.A., Zhou, X., Liu, P., Bai, Y., and Wu, Y.: An eddy-covariance system with an innovative vortex intake for measuring carbon dioxide and water fluxes of ecosystems, Atmos. Meas. Tech., 10, 1259-1267, https://doi.org/10.5194/amt-10-1259-2017, 2017.

Mammarella, I., Werle, P., Pihlatie, M., Eugster, W., Haapanala, S., Kiese, R., Markkanen, T., Rannik, Ü., and Vesala, T.: A case study of eddy covariance flux of $\mathrm{N}_{2} \mathrm{O}$ measured within forest ecosystems: quality control and flux error analysis, Biogeosciences, 7, 427-440, https://doi.org/10.5194/bg-7-4272010, 2010.

Mammarella, I., Peltola, O., Nordbo, A., Järvi, L., and Rannik, Ü.: Quantifying the uncertainty of eddy covariance fluxes due to the use of different software packages and combinations of processing steps in two contrasting ecosystems, Atmos. Meas. Tech., 9, 4915-4933, https://doi.org/10.5194/amt-9-4915-2016, 2016.

Massman, W. J.: A simple method for estimating frequency response corrections for eddy covariance systems, Agr. Forest Meteorol., 104, 185-198, 2000.

Massman, W. J. and Lee, X.: Eddy covariance flux corrections and uncertainties in long-term studies of carbon and energy exchanges, Agr. Forest Meteorol., 113, 121-144, 2002.

McBean, G. A.: Instrument requirements for eddy correlation measurements, J. Appl. Meteorol., 11, 1078-1084, 1972.

Merbold, L., Eugster, W., Stieger, J., Zahniser, M., Nelson, D., and Buchmann, N.: Greenhouse gas budget $\left(\mathrm{CO}_{2}, \mathrm{CH}_{4}\right.$, and $\left.\mathrm{N}_{2} \mathrm{O}\right)$ of intensively managed grassland following restoration, Glob. Change Biol., 20, 1913-1928, 2014.

Mishurov, M. and Kiely, G.: Nitrous oxide flux dynamics of grassland undergoing afforestation, Agr. Ecosyst. Environ., 139, 5965,2010

Mitsuta, Y.: Sonic Anemometer-Thermometer for General Use, J. Meteorol. Soc. Jpn., 44, 12-23, 1966.

Molodovskaya, M., Singurindy, O., Richards, B. K., Warland, J., Johnson, M. J., and Steenhuis, T. S.: Temporal Variability of Nitrous Oxide from Fertilized Croplands: Hot Moment Analysis, Soil Sci. Soc. Am. J., 76, 1728-1740, 2012.

Moore, C. J.: Frequency response corrections for eddy correlation systems, Bound. Lay. Meteorol., 37, 17-35, 1986.

Neftel, A., Ammann, C., Fischer, C., Spirig, C., Conen, F., Emmenegger, L., Tuzson, B., and Wahlen, S.: $\mathrm{N}_{2} \mathrm{O}$ exchange over managed grassland: Application of a quantum cascade laser spectrometer for micrometeorological flux measurements, Agr. Forest Meteorol., 150, 775-785, 2010.

Nelson, D. D., McManus, B., Urbanski, S., Herndon, S., and Zahniser, M. S.: High precision measurements of atmospheric nitrous oxide and methane using thermoelectrically cooled midinfrared quantum cascade lasers and detectors, Spectrochim. Acta A, 60, 3325-3335, 2004.

Novick, K., Walker, J., Chan, W., Schmidt, A., Sobek, C., and Vose, J.: Eddy covariance measurements with a new fastresponse, enclosed-path analyzer: Spectral characteristics and cross-system comparisons, Agr. Forest Meteorol., 181, 17-32, 2013.

Pattey, E., Strachan, I., Desjardins, R., Edwards, G., Dow, D., and MacPherson, J.: Application of a tunable diode laser to the measurement of $\mathrm{CH}_{4}$ and $\mathrm{N}_{2} \mathrm{O}$ fluxes from field to landscape scale using several micrometeorological techniques, Agr. Forest Meteorol., 136, 222-236, 2006.

Peltola, O., Hensen, A., Helfter, C., Belelli Marchesini, L., Bosveld, F. C., van den Bulk, W. C. M., Elbers, J. A., Haapanala, S., Holst, J., Laurila, T., Lindroth, A., Nemitz, E., Röckmann, T., Vermeulen, A. T., and Mammarella, I.: Evaluating the performance of commonly used gas analysers for methane eddy covariance flux measurements: the InGOS intercomparison field experiment, Biogeosciences, 11, 3163-3186, https://doi.org/10.5194/bg-11-3163-2014, 2014.

Pihlatie, M., Rinne, J., Ambus, P., Pilegaard, K., Dorsey, J. R., Rannik, Ü., Markkanen, T., Launiainen, S., and Vesala, T.: Nitrous oxide emissions from a beech forest floor measured by eddy covariance and soil enclosure techniques, Biogeosciences, 2, 377387, https://doi.org/10.5194/bg-2-377-2005, 2005.

Rannik, Ü., Haapanala, S., Shurpali, N. J., Mammarella, I., Lind, S., Hyvönen, N., Peltola, O., Zahniser, M., Martikainen, P. J., and Vesala, T.: Intercomparison of fast response commercial gas analysers for nitrous oxide flux measurements under field conditions, Biogeosciences, 12, 415-432, https://doi.org/10.5194/bg12-415-2015, 2015.

Reay, D. S., Davidson, E. A., Smith, K. A., Smith, P., Melilo, J. M., Dentener, F., and Crutzen, P. J. Global agriculture and nitrous oxide emissions, Nature Climate Change, 2, 410-416, 2012.

Risk, N., Snider, D., and Wagner-Riddle, C.: Mechanisms leading to enhanced soil nitrous oxide fluxes induced by freeze-thaw cycles, Can. J. Soil Sci., 93, 401-414, 2013. 
Salesky, S., Chamecki, M., and Dias, N.: Estimating the random error in eddy-covariance based fluxes and other turbulence statistics: The filtering method, Bound.-Lay. Meteorol., 114, 113-135, 2012.

Santos, E., Wagner-Riddle, C., and Warland, J.: Applying Lagrangian dispersion analysis to infer carbon dioxide and latent heat fluxes in a corn canopy, Agr. Forest Meteorol., 151, 620632, 2011.

Sargent, S.: Quantifying frequency response of a low-power, closedpath $\mathrm{CO}_{2}$ and $\mathrm{H}_{2} \mathrm{O}$ eddy-covariance system, Technical report, Campbell Scientific Inc, Logan, Utah, US, 10 pp., 2012.

Savage, K., Phillips, R., and Davidson, E.: High temporal frequency measurements of greenhouse gas emissions from soils, Biogeosciences, 11, 2709-2720, https://doi.org/10.5194/bg-112709-2014, 2014.

Scanlon, T. M. and Kiely, G.: Ecosystem-scale measurements of nitrous oxide fluxes for an intensely grazed, fertilized grassland, Geophys. Res. Lett., 30, 1-4, 2003.

Shurpali, N. J., Rannik, U., Jokinen, S., Lind, S., Biasi, C., Mammarella, I., Peltola, O., Pihlatie, M., Hyvonen, N., Raty, M., Haapanala, S., Zahniser, M., Virkajarvi, P., Vesala, T., and Martikainen, P. J.: Neglecting diurnal variations leads to uncertainties in terrestrial nitrous oxide emissions, Sci. Rep.-UK, 6, 25739, https://doi.org/10.1038/srep25739, 2016.

Sturm, P., Eugster, W., and Knohl, A.: Eddy covariance measurements of $\mathrm{CO}_{2}$ isotopologues with a quantum cascade laser absorption spectrometer, Agr. Forest Meteorol., 152, 73-82, 2012.

Yang, M., Bell, T. G., Hopkins, F. E., Kitidis, V., Cazenave, P. W., Nightingale, P. D., Yelland, M. J., Pascal, R. W., Prytherch, J., Brooks, I. M., and Smyth, T. J.: Air-sea fluxes of $\mathrm{CO}_{2}$ and $\mathrm{CH}_{4}$ from the Penlee Point Atmospheric Observatory on the southwest coast of the UK, Atmos. Chem. Phys., 16, 5745-5761, https://doi.org/10.5194/acp-16-5745-2016, 2016.
Wagner-Riddle, C., Thurtell, G., and Edwards, G.: Micrometeorology in Agricultural Systems, chapter Trace Gas Concentration Measurements for Micrometeorological Flux Quantification, American Society of Agronomy, Crop Science Society of America, Soil Sci. Soc. Am., 47, 321-343, 2005.

Wagner-Riddle, C., Furon, A., McLaughlin, N. L., Lee, I., Barbeau, J., Jayasundara, S., Parkin, G., von Bertoldi, P., and Warland, J. S.: Intensive management of nitrous oxide emissions from a corn-soybean-winter-wheat rotation under two contrasting management systems over 5 years, Glob. Change Biol., 13, 17221736, 2007.

Wagner-Riddle, C., Congreves, K. A., Abalos, D., Berg, A. A., Brown, S. E., Ambadan, J. T., Gao, X., and Tenuta, M.: Globally important nitrous oxide emissions from croplands induced by freeze-thaw cycles, Nat. Geosci., 10, 279-283, https://doi.org/10.1038/ngeo2907, 2017.

Wang, D., Wang, K., Díaz-Pinés, E., Zheng, X., and ButterbachBahl, K.: Applicability of an eddy covariance system based on a close-path quantum cascade laser spectrometer for measuring nitrous oxide fluxes from subtropical vegetable fields, Atmospheric and Oceanic Science Letters, 9, 381-387, 2016.

Webb, E. K., Pearman, G. I., and Leuning, R.: Correction of flux measurements for density effects due to heat and water vapour transfer, Q. J. Roy. Meteor. Soc., 106, 85-100, 1980. 